\section{(A) Check for updates}

Cite this: Dalton Trans., 2022, 51 5082

Received 6th February 2022 Accepted 4th March 2022

DOI: 10.1039/d2dt00371f

rsc.li/dalton

\title{
Synthesis of substituted (N,C) and (N,C,C) Au(III) complexes: the influence of sterics and electronics on cyclometalation reactions $\uparrow$
}

\author{
Knut T. Hylland, (D) * $+^{a, b}$ Inga L. Schmidtke, (D) $\ddagger^{a, b}$ David S. Wragg, (D) a,b \\ Ainara Nova (iD ${ }^{a, b, c, d}$ and Mats Tilset (D) *a,b,c
}

\begin{abstract}
Cyclometalated $\mathrm{Au}(\mathrm{III})$ complexes are of interest due to their catalytic, medicinal, and photophysical properties. Herein, we describe the synthesis of derivatives of the type $(N, C) A u\left(O A c^{F}\right)_{2}\left(O A c^{F}=\right.$ trifluoroacetate) and $(\mathrm{N}, \mathrm{C}, \mathrm{C}) \mathrm{AuOAC}^{\mathrm{F}}$ by a cyclometalation route, where $(\mathrm{N}, \mathrm{C})$ and $(\mathrm{N}, \mathrm{C}, \mathrm{C})$ are chelating 2-arylpyridine ligands. The scope of the synthesis is explored by substituting the 2-arylpyridine core with electron donor or acceptor substituents at one or both rings. Notably, a variety of functionalized Au(III) complexes can be obtained in one step from the corresponding ligand and $\mathrm{Au}(\mathrm{OAc})_{3}$, eliminating the need for organomercury intermediates, which is commonly reported for similar syntheses. The influence of substituents in the ligand backbone on the resulting complexes was assessed using DFT calculations, ${ }^{15} \mathrm{~N}$ NMR spectroscopy and single-crystal X-ray diffraction analysis. A correlation between the electronic properties of the $(\mathrm{N}, \mathrm{C})$ ligands and their ability to undergo cyclometalation was found from experimental studies combined with natural charge analysis, suggesting the cyclometalation at $\mathrm{Au}(\mathrm{III})$ to take place via an electrophilic aromatic substitution-type mechanism. The formation of $\mathrm{Au}($ (II) pincer complexes from tridentate (N,C, C) ligands was investigated by synthesis and DFT calculations, in order to assess the feasibility of $\mathrm{C}\left(\mathrm{sp}^{3}\right)-\mathrm{H}$ bond activation as a synthetic pathway to (N,C,C) cyclometalated Au(III) complexes. It was found that $\mathrm{C}\left(\mathrm{sp}^{3}\right)-\mathrm{H}$ bond activation is feasible for ligands containing different alkyl groups (isopropyl and ethyl), although the $\mathrm{C}-\mathrm{H}$ activation is less energetically favored compared to a ligand containing tert-butyl groups.
\end{abstract}

\section{Introduction}

(N,C)-Cyclometalated $\mathrm{Au}(\mathrm{III})$ complexes ${ }^{1-4}$ have found application within catalysis ${ }^{5-9}$ and medicine ${ }^{10-15}$ and have also gained attention for their photophysical properties., ${ }^{3,16-18}$ While cyclometalated $\mathrm{Au}(\mathrm{III})$ dichloro complexes have been known since the $1980 \mathrm{~s},{ }^{1}$ corresponding acetate and trifluoroacetate complexes are less studied. Due to the labile nature of carboxylate ligands, the reactivity of such complexes in e.g. ligand

\footnotetext{
${ }^{a}$ Department of Chemistry, University of Oslo, P.O. Box 1033, Blindern, N-0315 Oslo, Norway.E-mail:k.t.hylland@smn.uio.no,mats.tilset@kjemi.uio.no

${ }^{b}$ Centre for Materials Science and Nanotechnology, University of Oslo, P.O. Box 1126 Blindern, N-0316 Oslo, Norway

${ }^{c}$ Hylleraas Centre for Quantum Molecular Sciences, Department of Chemistry, University of Oslo, N-0315 Oslo, Norway

${ }^{d}$ UiT-The Arctic University of Norway, N-9037 Tromsø, Norway

$\dagger$ Electronic supplementary information (ESI) available. CCDC 2115512, 2122527, 2085151, 2086346, 2126159, 2126283, 2122284, 2111917, 2105655, 2086931, 2126114, 2130186, 2126097 and 2114274. For ESI and crystallographic data in CIF or other electronic format see DOI: 10.1039/d2dt00371f

$\$$ Co-first authors. These authors contributed equally to this work.
}

exchange reactions is higher than for their chloride analogues. ${ }^{2}$ Trifluoroacetate ligands are especially labile, making $\mathrm{Au}(\mathrm{III})$ trifluoroacetate complexes attractive catalyst candidates, ${ }^{5,7}$ as well as useful intermediates for the synthesis of other $\mathrm{Au}(\mathrm{III})$ complexes. ${ }^{19-22}$ In 2012 the first di(trifluoroacetate) complex of $\mathrm{Au}(\mathrm{III})$ with a chelating 2-arylpyridine ligand was reported by our group (2a-Au( $\left(\mathbf{O A c}^{\mathrm{F}}\right)_{2}$, Fig. 1$) \cdot{ }^{19}$ This complex was conveniently synthesized by reacting tpy (2-( $p$-tolyl)-pyridine, 1 a) with $\mathrm{Au}(\mathrm{OAc})_{3}$ in a 1:1 mixture of $\mathrm{HOAc}^{\mathrm{F}}$ (trifluoroacetic acid) and water, using microwave-heating. This was a further development of a protocol for the synthesis of (N,C) $\mathrm{Au}(\mathrm{III})$ dichloro complexes, such as $\mathbf{2 a - A u C l}{ }_{2}{ }^{23}$ (Fig. 1). The reactivity of $\mathbf{2 a}-\mathbf{A u}\left(\mathbf{O A} \mathbf{c}^{\mathbf{F}}\right)_{2}$ towards organolithium and Grignard reagents, ${ }^{19,20}$ ethylene, ${ }^{24,25}$ higher alkenes ${ }^{26}$ and acetylene ${ }^{7}$ has since then been explored. Subsequent to the initial findings, only few examples of trifluoroacetate complexes of $\mathrm{Au}$ (III) with 2-arylpyridine ligands have been reported. ${ }^{27-29}$ The scope of the microwave-assisted cyclometalation protocol has not been systematically investigated, although microwavemediated synthesis of $\mathrm{Au}(\mathrm{III})$ complexes has had an increase in popularity in the last decade..$^{3,30-36}$ 

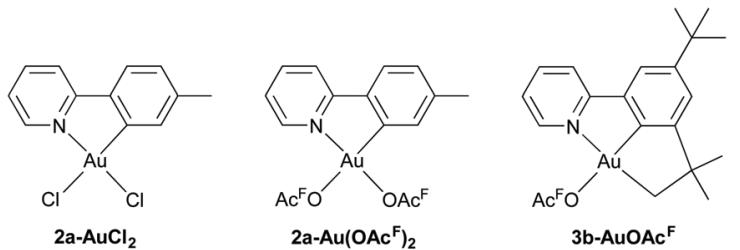

Previous work

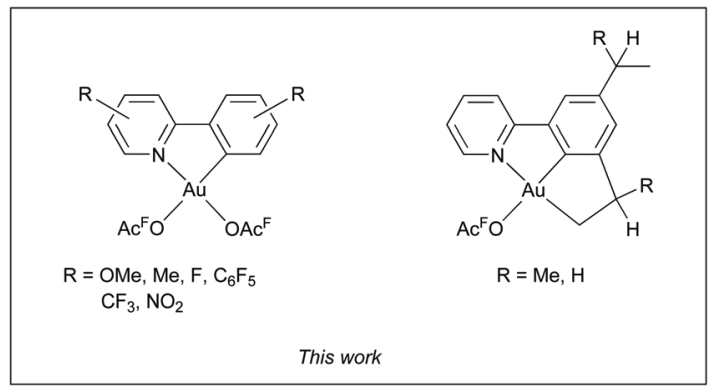

Fig. 1 Top: previously synthesized $A$ (III) complexes by our group: the $(\mathrm{N}, \mathrm{C})$ complexes $2 \mathrm{a}-\mathrm{AuCl}_{2}{ }^{23}$ and $\left.2 \mathrm{a}-\mathrm{Au}(\mathrm{OAc})_{2}\right)^{19}$ and the $(\mathrm{N}, \mathrm{C}, \mathrm{C})$ complex 3b-AuOAc ${ }^{\mathrm{F}}$. Bottom: $(\mathrm{N}, \mathrm{C})$ and $(\mathrm{N}, \mathrm{C}, \mathrm{C}) \mathrm{Au}(\mathrm{III})$ trifluoroacetate complexes studied herein.

(N,C,C) $\mathrm{Au}(\mathrm{III})$ pincer complexes have been reported to be more stable than $(\mathrm{N}, \mathrm{C})$ systems towards protolytic decomposition, ${ }^{8}$ and also possess interesting luminescence properties compared to $(\mathrm{C}, \mathrm{N}, \mathrm{C})$ and $(\mathrm{N}, \mathrm{C}) \mathrm{Au}(\mathrm{III})$ complexes. ${ }^{16}$ For $\mathrm{Au}(\mathrm{III})$, the majority of reported $(\mathrm{N}, \mathrm{C}, \mathrm{C})$ pincer ligands are derived from 2-([1,1'-biphenyl]-3-yl)pyridine (Fig. 2). ${ }^{2,16,18}$ While cyclometalation through $\mathrm{C}\left(\mathrm{sp}^{3}\right)-\mathrm{H}$ bond activation is common for e.g. $\mathrm{Pd}(\mathrm{II}),{ }^{37-40}$ reports on $\mathrm{C}\left(\mathrm{sp}^{3}\right)-\mathrm{H}$ bond activation in the synthesis of $\mathrm{Au}(\mathrm{III})$ complexes are scarce, and only a few examples have been reported. ${ }^{41-43}$ In 2018, we reported a rare example of $\mathrm{C}\left(\mathrm{sp}^{3}\right)-\mathrm{H}$ bond activation for $\mathrm{Au}(\mathrm{III})$ in the synthesis of an (N,C, C)-cyclometalated $\mathrm{Au}(\mathrm{III})$ trifluoroacetate complex $\mathbf{3 b} \mathbf{b}-\mathbf{A u O A c} \mathbf{c}^{\mathbf{F}}$ from 2-(3,5-di-tert-butylphenyl)pyridine (1b) (Fig. 1). ${ }^{8}$ The formation of complex $\mathbf{3} \mathbf{b}-\mathbf{A u O A} \mathbf{c}^{\mathbf{F}}$ from $\mathbf{1 b}$ was studied in detail by DFT calculations, showing that the steric bulk of the tert-butyl substituent promotes the $\mathrm{C}\left(\mathrm{sp}^{3}\right)-\mathrm{H}$ activation by destabilising the intermediate $(\mathrm{N}, \mathrm{C})$ complex.

To understand and develop the chemistry of organometallic $\mathrm{Au}(\mathrm{III})$ complexes, robust synthesis protocols are of high importance. Varying the functionalization of the ligand backbone in coordination compounds is of interest as this can have a significant impact on their catalytic, ${ }^{44-47}$ photophysical, ${ }^{2,16-18,48-55}$ magnetic, ${ }^{56,57}$ electrochemical ${ }^{58-62}$ and biological $^{63-65}$
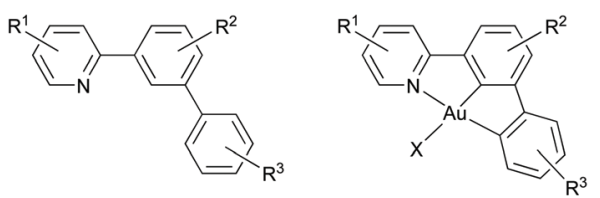

Fig. 2 Ligand for (N,C,C) Au(III) pincer formation derived from 2-([1,1'biphenyl]-3-yl)pyridine (left) and the corresponding $\mathrm{Au}(\mathrm{III})$ complex that possess two $\mathrm{Au}-\mathrm{C}\left(\mathrm{sp}^{2}\right)$ bonds (right). properties. Furthermore, it allows for the evaluation of the robustness of the metalation protocol. Therefore, we wanted to explore the possibility to synthesize functionalized derivatives of $\mathbf{2 a}-\mathbf{A u}\left(\mathbf{O A c} \mathbf{c}^{\mathbf{F}}\right)_{2}$ and $\mathbf{3 b} \mathbf{b}-\mathbf{A u O A c} \mathbf{c}^{\mathbf{F}}$ (see general structures in Fig. 1). Variation of the ancillary 2-arylpyridine ligand is easily implemented, particularly through cross-coupling reactions, and by this a series of new ligands for $\mathrm{Au}(\mathrm{III})$ is readily available. In addition, cyclometalation as a strategy for the synthesis of (N,C) and (N,C,C) Au(III) complexes remains a somewhat underdeveloped field. More traditional approaches, such as transmetalation of the corresponding organomercury compounds, are frequently being reported for the synthesis of cyclometalated $\mathrm{Au}$ (III) complexes. ${ }^{1,2,18,65-68}$ Although efficient, this method suffers from the toxicity of mercury, creating a need to investigate and further develop alternative synthesis methods. We herein present the synthesis and characterization of a series of $(\mathrm{N}, \mathrm{C})$ and (N,C,C) Au(III) complexes. All complexes were conveniently prepared by microwave-heating using $\mathrm{Au}(\mathrm{OAc})_{3}$ and the corresponding 2-arylpyridine ligand, with electron-donating or -withdrawing substituents at one or both rings. The formation and bonding properties of these complexes were assessed by DFT calculations, ${ }^{15} \mathrm{~N}$ NMR spectroscopy and single-crystal $\mathrm{X}$-ray diffraction analysis, in order to address any substituent effects.

\section{Results and discussion}

\section{Ligand synthesis}

The ligands, substituted 2-arylpyridines (1c-1u), were readily available through the Suzuki-Miyaura cross-coupling of suitable 2-halogenated pyridine derivatives and arylboronic acids (Scheme 1A), using reaction conditions reported in the literature. ${ }^{8,69,70}$ Ligand 1r was prepared from 1q (Scheme 1B) according to a method developed by Fagnou and co-workers for the installation of pentafluorophenyl groups through Pdcatalysed $\mathrm{C}-\mathrm{H}$ activation. ${ }^{71}$

\section{Synthesis of (N,C)-cyclometalated Au(III) di(trifluoroacetate) complexes}

Having in hand a wide variety of potential ligands, we investigated their ability to cyclometalate at $\mathrm{Au}(\mathrm{III})$ under the same reaction conditions as utilized for the synthesis of $\mathbf{2 a - A u}$ $\left(\mathbf{O A c}^{\mathbf{F}}\right)_{2}$ (Scheme 2). ${ }^{23}$

The $\mathrm{Au}(\mathrm{III})$ complexes were obtained in yields ranging from 27 to $95 \%$, and both electron-withdrawing (nitro, trifluoromethyl) and electron-donating (methyl, methoxy) substituents were tolerated. They were characterized by multinuclear NMR spectroscopy $\left({ }^{1} \mathrm{H},{ }^{13} \mathrm{C},{ }^{19} \mathrm{~F}\right.$ and ${ }^{15} \mathrm{~N}$ NMR $)$, MS, elemental analysis and single-crystal X-ray diffraction analysis. For $\mathrm{Au}(\mathrm{III})$ complexes carrying substituents on the pyridine ring, no clear trends in yields were observed. For complexes with substituents on the phenyl ring, certain trends in yields were found. For evaluation of the experimental observations, the carbon that undergoes cyclometalation in the protonated ligands $(\mathrm{C} 2$, see Scheme 3) was investigated by natural charge analysis. In 
A
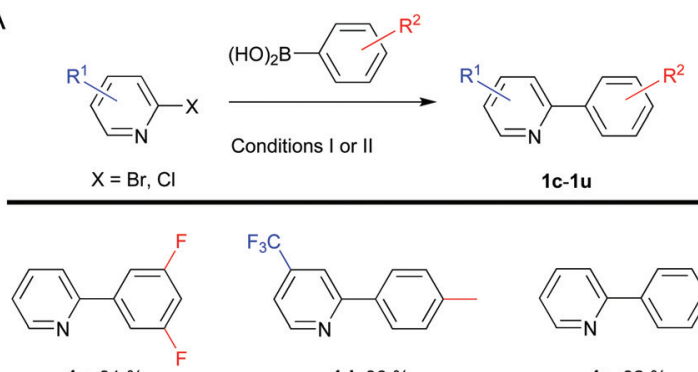

1d; $86 \%$
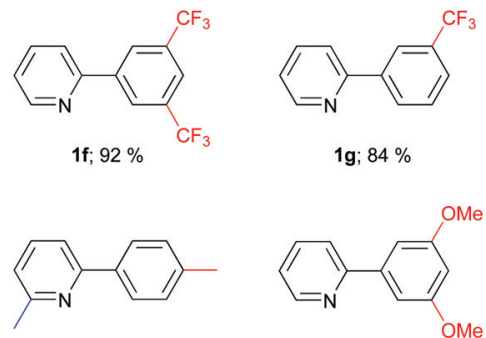

1i; $92 \%$

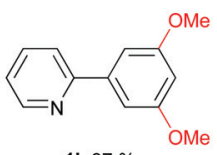

1j; $87 \%$

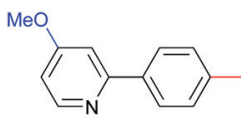

11; $89 \%$
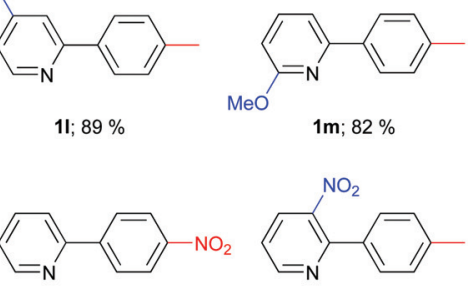

10; $63 \%$

1p; $67 \%$
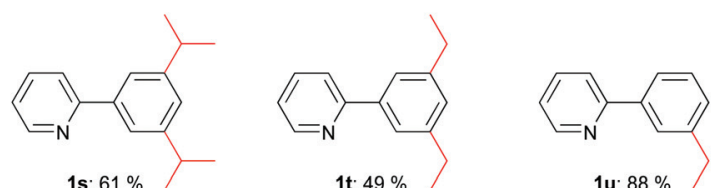

B
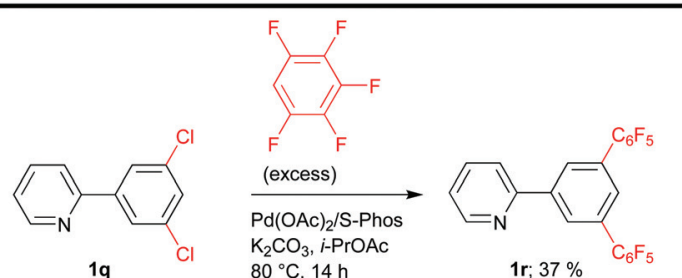

Scheme 1 (A) Synthesis of 2-arylpyridine ligands. Conditions $\mathrm{I}=\mathrm{Pd}$ $(\mathrm{OAC})_{2}, \mathrm{PPh}_{3}, \mathrm{~K}_{3} \mathrm{PO}_{4}, \mathrm{H}_{2} \mathrm{O}, n-\mathrm{PrOH}^{8}$ Conditions II $=\mathrm{Pd}_{2} \mathrm{dba}_{3}, \mathrm{HBF}_{4} \cdot \mathrm{P}(t-$ $\mathrm{Bu})_{3}, \mathrm{KF} \cdot 2 \mathrm{H}_{2} \mathrm{O}, \mathrm{THF}^{69,70}$ (B) Synthesis of ligand $1 \mathbf{r}$ from $1 \mathbf{q}$.

the following section, the natural charge of $\mathrm{C} 2$ ' in the ligands are discussed relative to the charge of $\mathrm{C} 2{ }^{\prime}$ in the 2-phenylpyridinium cation, $\mathbf{p p y}-\mathbf{H}^{+}\left(\Delta \mathrm{C} 2^{\prime}=0\right)$ (for full details, see ESI $\dagger$ ). The dimethyl-substituted complex $\mathbf{2 h}-\mathbf{A u}\left(\mathbf{O A} \mathbf{c}^{\mathbf{F}}\right)_{2}$ was obtained in high yield (95\%) like complex 2a-Au(OAc $\left.{ }^{\mathbf{F}}\right)_{2} \quad(94 \%){ }^{19}$ Complexes carrying either significantly electron-withdrawing

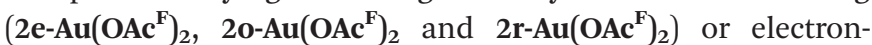
donating (2k-Au(OAc $\left.{ }^{\mathbf{F}}\right)_{2}$ ) groups were obtained in lower yields. The difluoro-substituted complex $2 \mathbf{c}-\mathbf{A u}\left(\mathbf{O A} \mathbf{c}^{\mathbf{F}}\right)_{2}$ was obtained
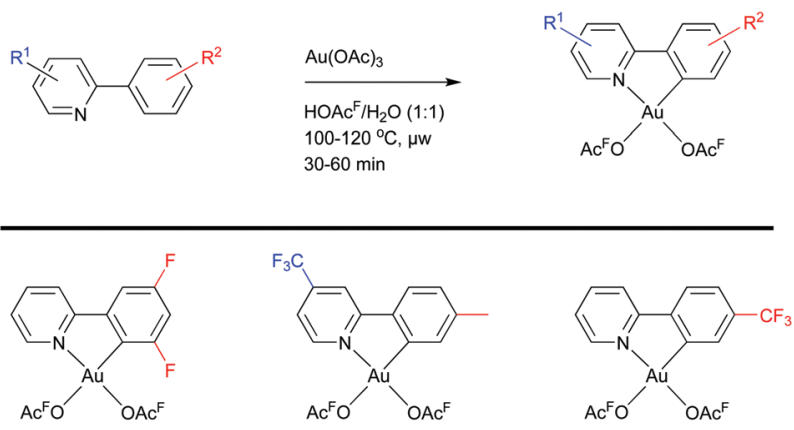

$2 c-A u\left(\mathrm{OAC}^{\mathrm{F}}\right)_{2} ; 85 \%$

2d-Au(OAC $\left.{ }^{F}\right)_{2} ; 64 \%$

2e-Au(OAC $\left.{ }^{\mathrm{F}}\right)_{2} ; 44 \%$
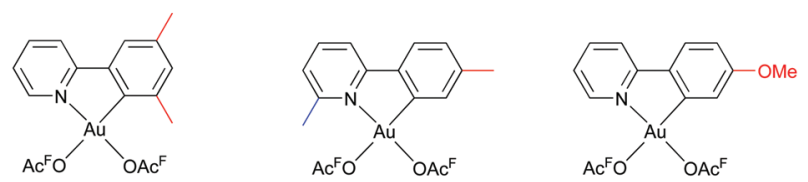

$2 h-A u\left(\mathrm{OAC}^{\mathrm{F}}\right)_{2} ; 95 \%$

$2 \mathrm{i}-\mathrm{Au}\left(\mathrm{OAC}^{\mathrm{F}}\right)_{2} ; 58 \%$
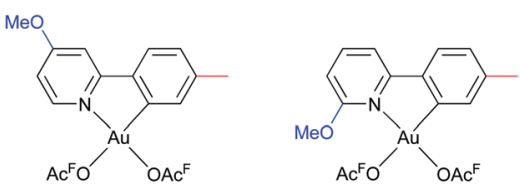

21-Au(OAC $\left.{ }^{\mathrm{F}}\right)_{2} ; 45 \%$
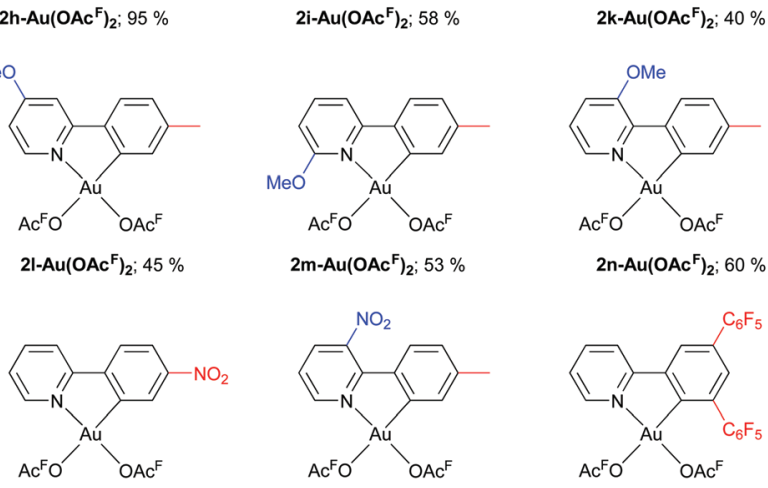

2o-Au(OAc $)_{2} ; 27 \%$

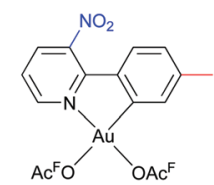

$2 p-A u\left(\mathrm{OAc}^{\mathrm{F}}\right)_{2} ; 65 \%$

Scheme 2 Microwave-mediated synthesis of (N,C)-cyclometalated $\mathrm{Au}$ (III) complexes.
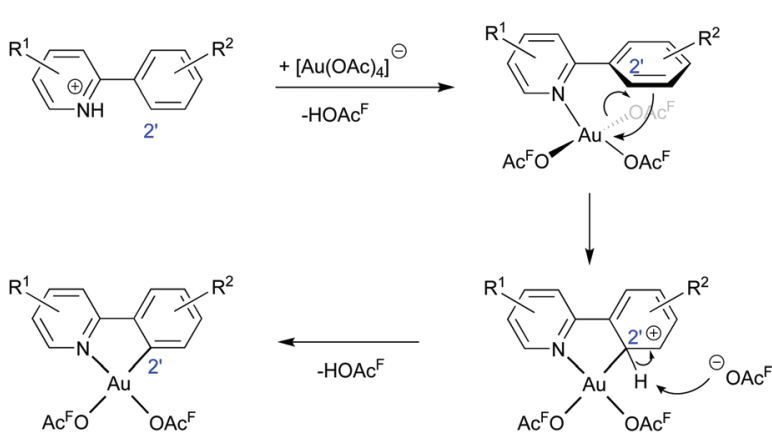

Scheme 3 Postulated mechanism for the formation of cyclometalated $\mathrm{Au}(\mathrm{III})$ complexes. The carbon $\left(\mathrm{C}^{\prime}\right)$ that undergoes the $\mathrm{C}\left(\mathrm{sp}^{2}\right)-\mathrm{H}$ bond activation and binds to gold in the final product is indicated.

in $85 \%$ yield, supporting an electrophilic aromatic substitution-type of cyclometalation mechanism (Scheme 3). This mechanism is generally preferred for the formation of cyclometalated complexes of late transition metals. ${ }^{72-76}$ Despite being inductively electron-withdrawing, fluorine groups are ortho/para-directing and activating substituents in aromatic electrophilic substitution reactions, causing the $\mathrm{C}\left(\mathrm{sp}^{2}\right)-\mathrm{H}$ acti- 
vation to proceed more easily at ligand $\mathbf{1 c}$ compared to e.g. 1e, 10 and 1 r.

Neither di(trifluoromethyl)- nor dimethoxy-substituted ligands $\mathbf{1 f}$ and $\mathbf{1 j}$ provided the desired cyclometalated products. The reaction of $\mathbf{1} \mathbf{j}$ and $\mathrm{Au}(\mathrm{OAc})_{3}$ furnished a multitude of species as seen in the ${ }^{1} \mathrm{H}$ NMR spectrum of the crude product (Fig. S89, ESI $\dagger$ ), and no single, clean compound could be isolated. It was however possible to obtain crystals suitable for single-crystal XRD, showing an unusual dinuclear $\mathrm{M}_{2} \mathrm{~L}_{3}$ type complex $\left(2 \mathbf{j}_{3} \mathbf{A u}_{2}(\mathbf{O A c})_{2}\right)_{2}$, see Fig. S146 and Fig. S147, ESI $\dagger$ ). Having said this, we do not believe this to be the main reaction product, as no other characterization data can substantiate this. We surmise that the ligand is too electron rich and reactive to yield clean formation of a $\mathrm{Au}(\mathrm{III})$ complex under the investigated reaction conditions. This assumption is further supported by the calculated natural charge for $\mathrm{C}^{\prime}$ in $\mathbf{1} \mathbf{j}-\mathbf{H}^{+}\left(\Delta \mathrm{C} 2^{\prime}=-0.120\right)$. The natural charge for $\mathrm{C} 2^{\prime}$ in $\mathbf{1} \mathbf{j}-\mathbf{H}^{+}$is significantly larger than the ones found for ligands $\mathbf{1} \mathbf{c}-\mathbf{H}^{+}$ $\left(\Delta \mathrm{C} 2^{\prime}=-0.084\right)$ and $\mathbf{1} \mathbf{h}-\mathbf{H}^{+}\left(\Delta \mathrm{C} 2^{\prime}=-0.008\right)$, which both have activating substituents in the $3^{\prime}$ - and $5^{\prime}$-positions. For di(trifluoromethyl)-substituted 1f, the $N$-coordinated adduct $\mathbf{1 f - A u}$ $\left.(\mathbf{O A c})_{3}\right)_{3}$ (which is a likely precursor for the cyclometalation step) was isolated (Scheme 4).

The failure of obtaining cyclometalated $2 \mathbf{f - A u}\left(\mathbf{O A c} \mathbf{c}^{\mathbf{F}}\right)_{2}$ can be related with the poor electrophilicity of $\mathbf{1 f}\left(\Delta \mathrm{C} 2^{\prime}=+0.061\right.$ for $\left.\mathbf{1 f}-\mathbf{H}^{+}\right)$. It was previously reported by our group that pincer complex 3b-AuOAc ${ }^{\mathbf{F}}$ (derived from the sterically encumbered and electron rich ligand $\mathbf{1 b}$ ) proceeds via the corresponding $(\mathrm{N}, \mathrm{C})$-cyclometalated complex $\mathbf{2 b}-\mathbf{A u}\left(\mathbf{O A c}{ }^{\mathbf{F}}\right)_{2}$ (see below). ${ }^{8}$ As the trifluoromethyl group is smaller than the tert-butyl

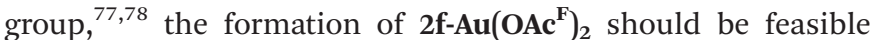
from a steric point-of-view. If the $\mathrm{Au}-\mathrm{C}$ bond formation takes place by electrophilic $\mathrm{C}\left(\mathrm{sp}^{2}\right)-\mathrm{H}$ bond activation (Scheme 3), (a) strongly electron-withdrawing substituent(s) in the aryl ring of the ligand might impede the reaction. Reaction of the monotrifluoromethyl-substituted ligand $1 \mathrm{~g}$ with $\mathrm{Au}(\mathrm{OAc})_{3}$ gave a $c a$. $2: 1$ mixture of the two regioisomers $2 \mathbf{g}-\boldsymbol{p}$ - $\left.\mathbf{A u}(\mathbf{O A c})_{2}\right)_{2}$ and $2 \mathbf{g}-\boldsymbol{o}$ $\mathbf{A u}\left(\mathbf{O A c}^{\mathbf{F}}\right)_{2}$ (Scheme 5). Thus, cyclometalation of $\mathrm{Au}(\mathrm{III})$ is compatible with the steric demands of an ortho-trifluoromethyl group. This result therefore suggests that the electronic influence is the main reason for the failure to produce $\mathbf{2 f - A u}$ $\left(\mathbf{O A c} \mathbf{c}^{\mathbf{F}}\right)_{2}$, as the di(trifluoromethyl)-substituted ligand $\mathbf{1 f}$ is more electron deficient than the corresponding mono-trifluoromethyl-substituted ligand $\mathbf{1 g}\left(\Delta \mathrm{C} 2^{\prime}=+0.025\right.$ for $\mathbf{1 g}-\boldsymbol{p}-\mathbf{H}^{+}$and $\Delta \mathrm{C} 2^{\prime}=+0.038$ for $\left.\mathbf{1 g}-\boldsymbol{o}-\mathbf{H}^{+}\right)$.

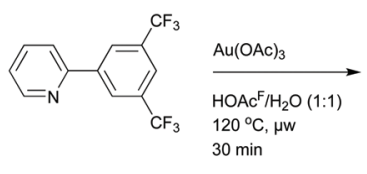

$1 f$

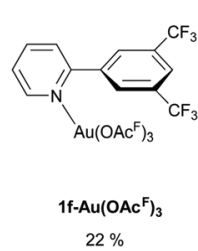

$22 \%$

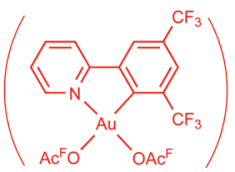

2f-Au $\left(\mathrm{OAC}^{\mathrm{F}}\right)_{2}$ not observed
Scheme 4 Synthesis of $1 \mathrm{f}-\mathrm{Au}(\mathrm{OAc})_{3}$. The corresponding $(\mathrm{N}, \mathrm{C})$ complex $2 \mathrm{f}-\mathrm{Au}\left(\mathrm{OAc} \mathrm{C}^{\mathrm{F}}\right)_{2}$ was not observed.

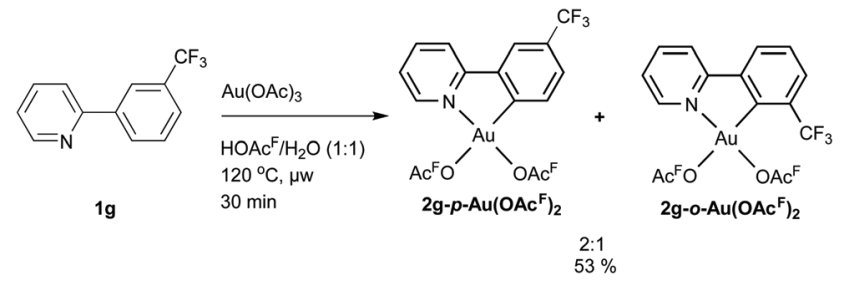

Scheme 5 Reactivity of ligand $1 \mathrm{~g}$ towards $\mathrm{Au}(\mathrm{OAc})_{3}$.

\section{Synthesis of (N,C,C)-cyclometalated Au(III) trifluoroacetate pincer complexes}

Following the successful microwave-mediated synthesis of pincer complex 3b-AuOAc ${ }^{\mathbf{F}}$ via $\mathrm{C}\left(\mathrm{sp}^{2}\right)-\mathrm{H}$ and $\mathrm{C}\left(\mathrm{sp}^{3}\right)-\mathrm{H}$ bond activation of ligand $\mathbf{1 b}$ (Fig. 3 ), ${ }^{8}$ we sought to investigate related tridentate ligands $(\mathbf{1 s}-\mathbf{1} \mathbf{u})$ in order to get more insight into the scope and limitations of the pincer formation. DFT calculations on the formation of $\mathbf{3 b} \mathbf{b}-\mathbf{A u O A c} \mathbf{c}^{\mathbf{F}}$ suggested the directing effect of the bulky tert-butyl group in ligand $\mathbf{1 b}$ to be a key element in the successful synthesis of the complex. ${ }^{8}$ Therefore, ligands $\mathbf{1 s}$ and 1t with less sterically demanding substituents, but otherwise an identical substitution pattern to that of $\mathbf{1 b}$ were investigated as tridentate ligands for $\mathrm{Au}(\mathrm{III})$. Additionally, the mono-substituted analogue of $\mathbf{1 t}$, ligand $\mathbf{1} \mathbf{u}$, was investigated in order to probe the selectivity of pincer formation relative to $(\mathrm{N}, \mathrm{C})$ cyclometalation.

Attempts of synthesizing $3 \mathbf{s}-\mathbf{A u O A c} \mathbf{c}^{\mathbf{F}}$ in an analogous manner (microwave heating at $120{ }^{\circ} \mathrm{C}$ for $30 \mathrm{~min}$ ) to $\mathbf{3 b}$ $\operatorname{AuOAc}^{\mathbf{F}}$ failed, and the $N$-coordinated adduct of ligand $1 \mathrm{~s}, \mathbf{1 s}$ $\mathbf{A u}\left(\mathbf{O A c}^{\mathbf{F}}\right)_{3}$, was the main species observed in the ${ }^{1} \mathrm{H}$ NMR spectrum of the crude product. The combination of lower reaction temperature $\left(80^{\circ} \mathrm{C}\right)$ and longer reaction time $(3.5 \mathrm{~h})$ did however furnish the pincer complex $3 \mathbf{s}-\mathbf{A u O A c}^{\mathbf{F}}$ in moderate yields (38\%) (Scheme 6). It is noteworthy that the $\mathrm{C}\left(\mathrm{sp}^{3}\right)-\mathrm{H}$ bond activation of the isopropyl group introduces a chiral
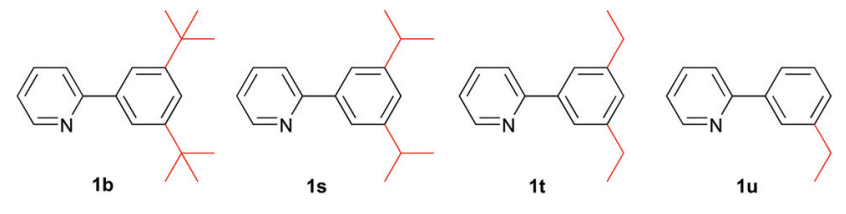

Fig. 3 Tridentate (N,C,C) ligands.
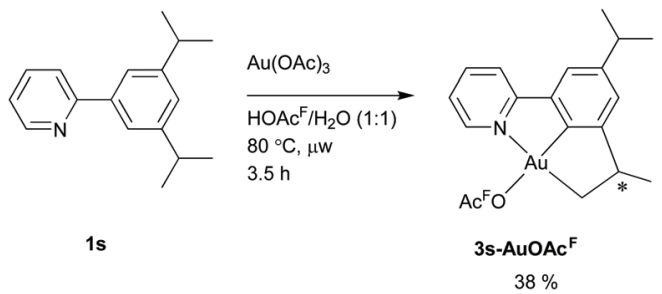

Scheme 6 Synthesis of $3 s-A u O A c{ }^{F}$. The star indicates the chiral centre that is formed upon $\mathrm{C}\left(\mathrm{sp}^{3}\right)-\mathrm{H}$ bond activation. 
centre in close proximity to gold in $\mathbf{3 s - A u O A c} \mathbf{F}^{\mathbf{F}}$, which has previously been observed for a structurally related Pt(Iv) complex. ${ }^{79}$ We did not attempt to resolve the enantiomers, but the accessibility to chiral centres through cyclometalation is a topic that deserves further investigation, especially if an enantiopure complex can be obtained. ${ }^{80}$

By employing the reaction conditions in Scheme 6, the ethyl analogue $3 \mathbf{t}-\mathbf{A u O A c} \mathbf{F}^{\mathbf{F}}$ was obtained in a good yield (65\%) from ligand 1t. In addition to the synthesis of $3 \mathbf{s}-\mathbf{A u O A c}{ }^{\mathbf{F}}$ and 3t-AuOAc ${ }^{\mathbf{F}}$, mono-ethyl-substituted $\mathbf{1} \mathbf{u}$ was explored as a tridentate ligand for $\mathrm{Au}(\mathrm{III})$. The reaction of $\mathbf{1} \mathbf{u}$ with $\mathrm{Au}(\mathrm{OAc})_{3}$ yielded the desired pincer complex $\mathbf{3 u}$-AuOAc ${ }^{\mathbf{F}}$ as a mixture with the corresponding (N,C)-cyclometalated complex $\left.\mathbf{2 u - p - A u ( O A c}{ }^{\mathbf{F}}\right)_{2}$ (Scheme 7). The other possible (N,C)-cyclometalated complex $2 \mathbf{u}-\boldsymbol{o}-\mathbf{A u}\left(\mathbf{O A c} \mathbf{c}^{\mathbf{F}}\right)_{2}$ could not be observed, supporting the involve-

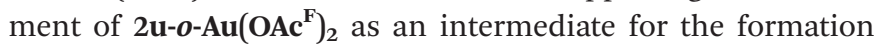
of $3 \mathbf{u}-\mathbf{A u O A c}^{\mathbf{F}}$ (see ESI $\dagger$ for details). To summarize, the successful syntheses of $\mathbf{3 s - A u O A c} \mathbf{c}^{\mathbf{F}}$ and $\mathbf{3 t - A u O A c} \mathbf{c}^{\mathbf{F}}$ show that the sterically induced pre-orientation of the $\mathrm{C}-\mathrm{H}$ bond that is activated (as seen in ligand $\mathbf{1 b}$ ) is not a strict requirement for $\mathrm{C}\left(\mathrm{sp}^{3}\right)-\mathrm{H}$ activation at $\mathrm{Au}(\mathrm{III})$, although the experimental observations suggest that the process is more feasible for $\mathbf{1 b}$ compared to $\mathbf{1 s}$ and 1t. Importantly, the results show that cyclometalation of $\mathrm{Au}(\mathrm{III})$ through $\mathrm{C}\left(\mathrm{sp}^{3}\right)-\mathrm{H}$ bond activation takes place at a $\beta$ position regardless of the nature of the alkyl group in the ligand.

\section{Single-crystal X-ray diffraction analysis of (N,C)- and (N,C,C)- cyclometalated $\mathrm{Au}(\mathrm{III})$ complexes}

Several of the (N,C)-cyclometalated Au(III) complexes were analysed by single-crystal X-ray diffraction (Fig. 4). In all cases, the complexes crystallized with the expected square planar geometry around $\mathrm{Au}(\mathrm{III})$. Deviations from ideal square planar geometries were evaluated by the $\tau^{\prime}{ }_{4}$ values ( 0 for square planar complexes, 1 for tetrahedral complexes $)^{81,82}$ of the structures, which were found in the range from 0.02 to 0.09 (Table 1). All $\mathrm{Au}$-ligand bond distances and angles are given in Table 1. The bond angles are similar to those previously reported for structurally related square planar Au(III) complexes. ${ }^{19,21,26,29}$ The Au1-N1 and Au1-C7 bond lengths are in the range of 1.9974

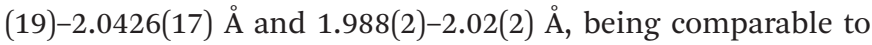
those reported for $\left.\mathbf{2 a - A u}(\mathbf{O A c})_{2}\right)_{2}(1.991(6) \AA$ and 1.995(7) $\AA$, respectively). ${ }^{19}$ The Au1-O3 (trans to $\mathrm{N}$ ) bond lengths are in the range of 2.0032(16)-2.034(3) $\AA$, all being slightly longer than the corresponding bond length in $\mathbf{2 a - A u}\left(\mathbf{O A c} \mathbf{c}^{\mathbf{F}}\right)_{2}(1.993(5)$

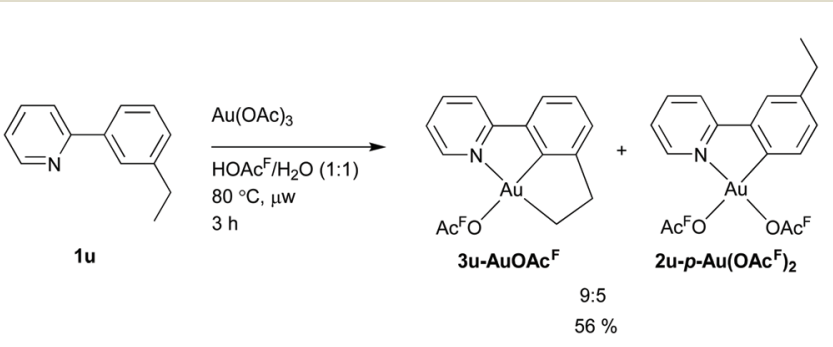

Scheme 7 Reactivity of ligand $1 \mathrm{u}$ towards $\mathrm{Au}(\mathrm{OAc})_{3}$.
$\AA$ ). Larger variation is found in the Au1-O1 (trans to C) bond lengths. In $2 \mathbf{c}-\mathbf{A u}\left(\mathbf{O A c}^{\mathbf{F}}\right)_{2}$, the Au1-N1 and Au1-C7 bond lengths are comparable to the other complexes, but a slightly shorter Au1-O1 (trans to carbon) bond is noted (2.070(3) ̊ for 2c-Au(OAc $\left.{ }^{\mathbf{F}}\right)_{2}$ vs. 2.095(13)-2.1185(16) $\AA$ for the rest of the complexes). This may be attributed to the presence of the electronwithdrawing fluorine substituents in the ligand, making the phenyl ring a weaker trans influence ligand compared to the one in e.g. 2a-Au(OAc $\left.{ }^{\mathbf{F}}\right)_{2}$. Similar, but less pronounced, shortening of the Au1-O1 bond can be observed for other complexes having electron-withdrawing substituents $\left(\mathbf{2 e - A u}\left(\mathbf{O A c} \mathbf{c}^{\mathbf{F}}\right)_{2}\right.$, 2o-Au(OAc $\left.{ }^{\mathbf{F}}\right)_{2}$ and $2 \mathbf{r}-\mathbf{A u}\left(\mathbf{O A c}^{\mathbf{F}}\right)_{2} ;$ Au1-O1 = 2.1026(18) $\AA$, 2.0984 (16) A and 2.095(13) Å, respectively).

For 3',5'-disubstituted complexes 2c-Au(OAc $\left.{ }^{\mathbf{F}}\right)_{2}, \quad 2 \mathbf{h}-\mathbf{A u}$ $\left(\mathbf{O A c}^{\mathbf{F}}\right)_{2}$ and $\left.\mathbf{2 r - A u}(\mathbf{O A c})_{2}\right)_{2}$ the O3-Au1-C7 cis angles (98.89 $(14)^{\circ}, 99.68(8)^{\circ}$ and $98.0(6)^{\circ}$, respectively) were slightly larger than in the other complexes (see Table 1). The angle was larger for $\mathbf{2 h}-\mathbf{A u}\left(\mathbf{O A c} \mathbf{c}_{\mathbf{F}}\right)_{2}$ than for $\mathbf{2 r}-\mathbf{A u}\left(\mathbf{O A c} \mathbf{c}^{\mathbf{F}}\right)_{2}$, being in accordance with literature reports of the similar effective steric bulk of the pentafluorophenyl group and the methyl group. ${ }^{83}$

The Au1-N1 bond lengths of $2 \mathbf{i}-\mathbf{A u}\left(\mathbf{O A c} \mathbf{c}^{\mathbf{F}}\right)_{2}$ and $2 \mathbf{m}-\mathbf{A u}$ $\left.(\mathbf{O A c})_{2}\right)_{2}$ are 2.034(3) $\AA$ and 2.0426(17) $\AA$, respectively, being longer than the corresponding Au1-N1 bond in the other complexes studied. Furthermore, the N1-Au1-O1 cis angles in 2i-

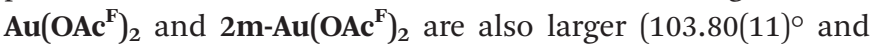
$104.62(6)^{\circ}$, respectively) compared to the other complexes $\left(91.37(12)^{\circ}-99.00(8)^{\circ}\right)$. Similar elongation of the Au1-N1 bond and widening of the corresponding cis angle have earlier been reported by Cinellu and co-workers for a structurally similar (N,C) $\mathrm{Au}(\mathrm{III})$ complex derived from 6,6'-dimethoxy-2,2'-bipyridine. $^{84}$ The N1-C1-O5 angle in $2 \mathbf{m}-\mathbf{A u}\left(\mathbf{O A c}^{\mathbf{F}}\right)_{2}$ is $114.51(18)^{\circ}$, being slightly smaller than the corresponding $\mathrm{N}-\mathrm{C}-\mathrm{O}$ (alkoxy) angles in reported crystal structures of non-coordinated pyridines, bipyridines or phenanthrolines with alkoxy substituents $\alpha$ to nitrogen (typically around $\left.120^{\circ}\right) .{ }^{40,84-88}$ The angle is similar to the $\mathrm{N}-\mathrm{C}-\mathrm{O}$ (alkoxy) angle in (N,C) $\mathrm{Au}(\mathrm{III})$ and $\mathrm{Pd}(\mathrm{II})$ complexes derived from 6,6'-dimethoxy-2,2'-bipyridine reported by Cinellu and co-workers. ${ }^{40,84}$ The relatively small N$\mathrm{C}-\mathrm{O}\left(\right.$ alkoxy) angle in $\mathbf{2 m - A u}\left(\mathbf{O A c}{ }^{\mathbf{F}}\right)_{2}$, together with a Au1-O5 distance of $3.13 \AA$ may hint at a weak interaction between the gold centre and the oxygen atom in the methoxy group. This was further investigated by means of ${ }^{15} \mathrm{~N}$ NMR spectroscopy (see below). The N1-C1-C13 angle (120.9(3) ${ }^{\circ}$ ) in 6-methyl-substituted $2 \mathbf{i}-\mathbf{A u}\left(\mathbf{O A c} \mathbf{c}^{\mathbf{F}}\right)_{2}$ is slightly larger than the corresponding $\mathrm{N}-\mathrm{C}-\mathrm{C}($ alkyl) angles in reported crystal structures of non-coordinated pyridines, bipyridines or phenanthrolines with alkyl substituents $\alpha$ to nitrogen (typically around $115^{\circ}$ ). ${ }^{89-93}$ This indicates that $\mathrm{Au}(\mathrm{III})$ coordination to 6-methyl-substituted pyridines results in a widening of the $\mathrm{N}-\mathrm{C}-\mathrm{C}($ methyl) angle, contrary to the effect $\mathrm{Au}(\mathrm{III})$ coordination has on the $\mathrm{N}-\mathrm{C}-\mathrm{O}$ (methoxy) angle in 6-methoxy-substituted pyridines. The $\mathrm{N}-\mathrm{C}-$ $\mathrm{C}\left(\right.$ alkyl) angle in $\mathbf{2} \mathbf{i}-\mathbf{A u}\left(\mathbf{O A} \mathbf{c}^{\mathbf{F}}\right)_{2}$ is similar to reported angles for related square planar $\mathrm{Au}(\mathrm{III})^{94}$ and $\mathrm{Pd}(\mathrm{II})^{58}$ complexes of 6-methyl-substituted (bi)pyridine ligands.

$\mathrm{Au}(\mathrm{III})$ pincer complexes 3s-AuOAc${ }^{\mathbf{F}}$ and $\mathbf{3 t}$-AuOAc ${ }^{\mathbf{F}}$ were also crystallographically characterized (Fig. 5). Both complexes crys- 

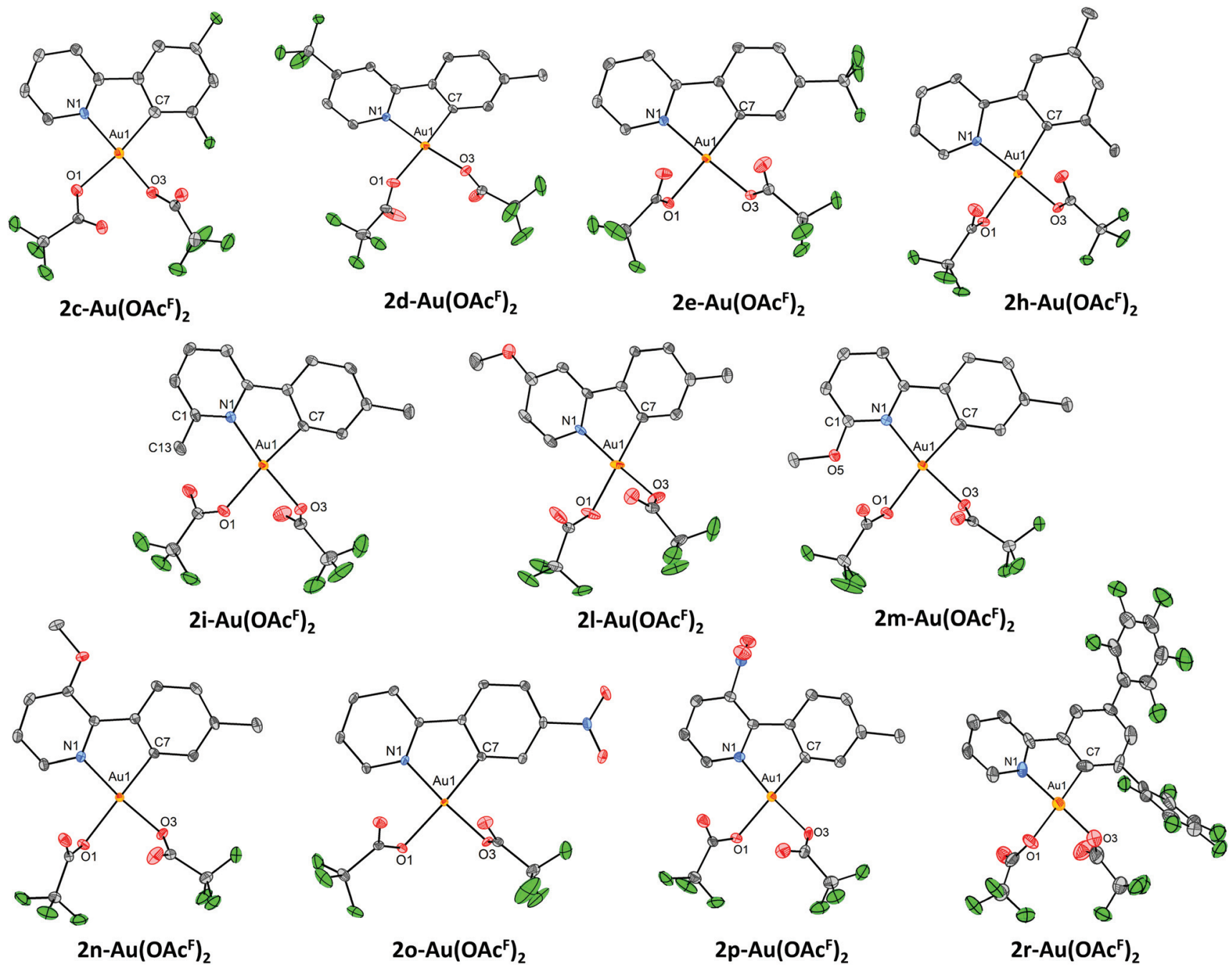

Fig. 4 ORTEPs of $2 c-A u\left(O A c^{F}\right)_{2}, 2 d-A u\left(O A c^{F}\right)_{2}, 2 e-A u\left(O A c^{F}\right)_{2}, 2 h-A u\left(O A c^{F}\right)_{2}, 2 i-A u\left(O A c^{F}\right)_{2}, 2 l-A u\left(O A c^{F}\right)_{2}, \quad 2 m-A u\left(O A c^{F}\right)_{2}, \quad 2 n-A u\left(O A c^{F}\right)_{2}, \quad 2 o-A u$ $(\mathrm{OAc})_{2}, 2 p-A u\left(O A c^{F}\right)_{2}$ and $2 r-A u\left(O A c^{F}\right)_{2}$. Ellipsoids are shown at $50 \%$ probability level. Hydrogen atoms and associated (disordered) solvent molecules (for $2 \mathrm{~d}-\mathrm{Au}\left(\mathrm{OAc} \mathrm{c}_{2}\right)_{2}, 2 \mathrm{i}-\mathrm{Au}\left(\mathrm{OAc} \mathrm{c}^{\mathrm{F}}\right)_{2}, 2 \mathrm{~m}-\mathrm{Au}\left(\mathrm{OAc} \mathrm{c}^{\mathrm{F}}\right)_{2}$ and $2 \mathrm{p}-\mathrm{Au}\left(\mathrm{OAc} \mathrm{c}_{2}\right)_{2}$ ) have been removed for clarity. For $2 \mathrm{~d}-\mathrm{Au}\left(\mathrm{OAc} \mathrm{c}_{2}\right)_{2}$ and $2 \mathrm{i}-\mathrm{Au}\left(\mathrm{OAc} \mathrm{c}^{\mathrm{F}}\right)_{2}$, only one of the two molecules in the asymmetric unit of each structure is shown. For $2 \mathrm{~d}-\mathrm{Au}\left(\mathrm{OAc} \mathrm{c}_{2}^{\mathrm{F}}\right)_{2}$ and $2 \mathrm{l}-\mathrm{Au}(\mathrm{OAc})_{2}$, disorder in the trifluoroacetate ligands have been removed for clarity. For more details, see ESI. $\dagger$

Table $1 \tau_{4}^{\prime}$ values and selected bond lengths $(\AA)$ and angles $\left({ }^{\circ}\right)$ for $(\mathrm{N}, \mathrm{C}) \mathrm{Au}(\mathrm{III})$ complexes

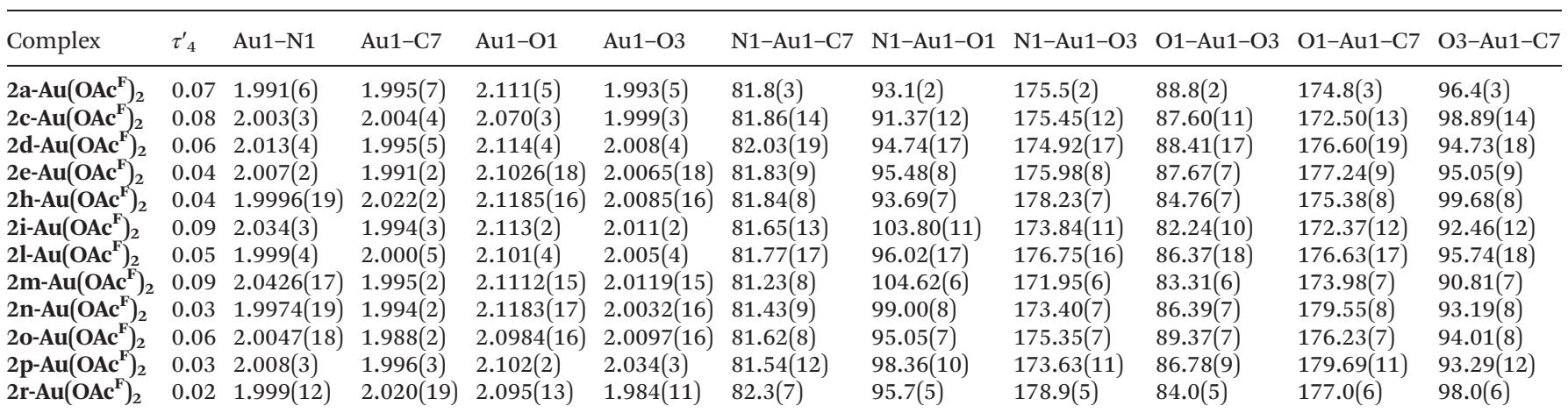

The corresponding data for $\mathbf{2} \mathbf{a}-\mathbf{A u}\left(\mathbf{O}\left(\mathbf{O A c}^{\mathbf{F}}\right)_{2}\right.$ are included for reference purposes. ${ }^{19}$ For $\mathbf{2 d - A u}\left(\mathbf{O A c} \mathbf{c}^{\mathbf{F}}\right)_{2}$ and $2 \mathbf{i}-\mathbf{A u}\left(\mathbf{O A c} \mathbf{c}^{\mathbf{F}}\right)_{2}$, metric data for one of the two molecules in the respective asymmetric unit are listed. See ESI (Fig. S140 and Fig. S145) † for metric data for both molecules in each asymmetric unit. 


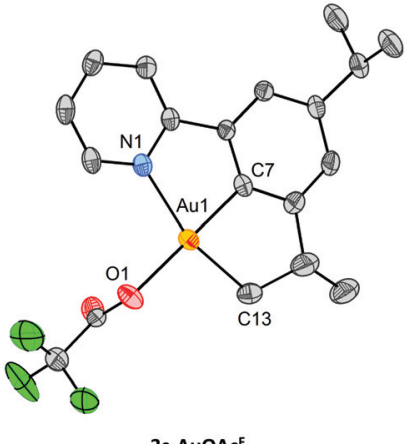

3s-AuOAcF

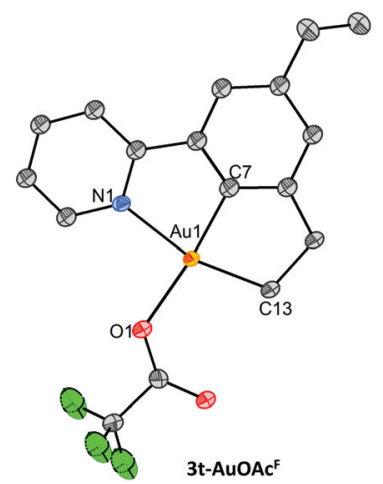

Fig. 5 ORTEPs of $3 s-A u O A c^{F}$ and $3 t-A u O A c^{F}$. Ellipsoids are shown at $50 \%$ probability level. Hydrogen atoms and disorder in the isopropyl group in $3 s-A u O A c^{F}$ have been omitted for clarity. Only one of the two molecules in the asymmetric unit is shown for $3 s-A u O A c^{F}$, and only one of the four molecules in the asymmetric unit is shown for $3 t-A u O A c^{F}$. For more details, see ESI. $\dagger$

tallized with distorted square planar geometry around $\mathrm{Au}(\mathrm{III})$ $\left(\tau^{\prime}{ }_{4}=0.09\right.$ for $3 \mathbf{s}-\mathbf{A u O A c}{ }^{\mathbf{F}}$ and $\tau^{\prime}{ }_{4}=0.11$ for $\left.\mathbf{3 t - A u O A c} \mathbf{F}^{\mathbf{F}}\right)$. The bond lengths and angles of the complexes are similar to those reported for $\mathbf{3 b} \mathbf{b}-\mathbf{A u O A} \mathbf{c}^{\mathbf{F}}$ (Table 2). Interestingly, only one enantiomer of the racemic mixture of pincer complex $3 \mathbf{s}-\mathbf{A u O A c} \mathbf{F}^{\mathbf{F}}$ could be modelled as the major component during refinement of the single-crystal X-ray structure.

\section{${ }^{15}$ N NMR spectroscopic studies of cyclometalated Au(III) complexes}

Some of the complexes and ligands discussed herein were investigated by ${ }^{15} \mathrm{~N}$ NMR spectroscopy, and coordination shifts $\Delta \delta^{15} \mathrm{~N}\left(\delta^{15} \mathrm{~N}_{\text {complex }}-\delta^{15} \mathrm{~N}_{\text {ligand }}\right)$ were obtained in order to gain insight about the $\mathrm{Au}-\mathrm{N}$ interactions. Furthermore, a selection of previously reported tpy-ligated Au(III) complexes $8,14,19,22,25,95$ with varying substituents cis and trans to pyridine- $\mathrm{N}$ was studied by ${ }^{15} \mathrm{~N}$ NMR spectroscopy to shed light on which factors influence the ${ }^{15} \mathrm{~N}$ NMR chemical shifts of $\mathrm{N}$-ligated square planar $\mathrm{d}^{8}$ metal complexes (Fig. 6).

$\Delta \delta^{15} \mathrm{~N}$ were found in the range of $-88.2 \mathrm{ppm}$ to $-104.5 \mathrm{ppm}$ for the (N,C) di(trifluoroacetate) $\mathrm{Au}(\mathrm{III})$ complexes (except for $\left.\mathbf{2 m - A u}(\mathbf{O A c})_{2}\right)_{2}$; see discussion below). These shifts are similar to reported data for other pyridine-ligated Au(III) complexes with weak trans influence ligands trans to nitrogen. ${ }^{44,96-98}$ The ${ }^{15} \mathrm{~N}$ NMR data can be interpreted in a similar manner as the data from the single-crystal X-ray diffraction analysis of the complexes, where the $\mathrm{Au}-\mathrm{N}$ bond lengths were found to be little dependent of the substituents in the ligand backbone. This reflects that other factors, such as the ligand trans to pyridine- $\mathrm{N},{ }^{99}$ affects $\Delta \delta^{15} \mathrm{~N}$ stronger than the substituents on the pyridine ring. Similar observations have also been reported by Pazderski for square planar Pd(II) and Pt (II) complexes with substituted bipyridine and phenanthroline ligands. ${ }^{96}$

The coordination shift of the 6-methoxy-substituted complex $2 \mathbf{m}-\mathbf{A u}\left(\mathbf{O A c}^{\mathbf{F}}\right)_{2}\left(\Delta \delta^{15} \mathrm{~N}=-66.1 \mathrm{ppm}\right)$ is significantly smaller than those of the other substituted di(trifluoroacetate) complexes. It seems likely that the relatively small $\Delta \delta^{15} \mathrm{~N}$ found for $\mathbf{2 m - A u}\left(\mathbf{O A c} \mathbf{c}^{\mathbf{F}}\right)_{2}$ is a result of the weak interaction between the methoxy-oxygen and gold. This potential interaction was also observed in the single-crystal structure of the $\mathrm{Au}(\mathrm{III})$ complex. The coordination shift for the 6-methyl-substituted complex $\mathbf{2} \mathbf{i}-\mathbf{A u}\left(\mathbf{O A c} \mathbf{F}^{\mathbf{F}}\right)_{\mathbf{2}}(-88.2 \mathrm{ppm})$ was in the same range as those obtained for the other di(trifluoroacetate) complexes studied herein, although the $\mathrm{Au}-\mathrm{N}$ bond length in the crystal structure of $\mathbf{2} \mathbf{i}-\mathbf{A u}\left(\mathbf{O A} \mathbf{c}^{\mathbf{F}}\right)_{2}(2.034(3) \AA)$ was similar to the one observed for $\mathbf{2 m - A u}\left(\mathbf{O A c} \mathbf{c}^{\mathbf{F}}\right)_{2}(2.0426(17) \AA)$. The very similar $\mathrm{Au}-\mathrm{N}$ bond lengths in the two complexes strengthens the argument that the relatively small coordination shift obtained for $2 \mathbf{m}-\mathbf{A u}\left(\mathbf{O A c}^{\mathbf{F}}\right)_{2}$ is caused by an interaction between oxygen and gold, rather than steric repulsion between gold and the 6-substituent. ${ }^{84}$ If this was the case, it would be expected to yield a comparable coordination shift for $\mathbf{2} \mathbf{i}-\mathbf{A u}\left(\mathbf{O A c}^{\mathbf{F}}\right)_{2}$.

For complex $\mathbf{1 f - A u}(\mathbf{O A c})_{3}^{\mathbf{F}}, \quad \Delta \delta^{15} \mathrm{~N}$ was found to be -114.1 ppm, larger than what was observed for the cyclometalated complexes and also larger than what has been reported for pyridine-ligated $\mathrm{AuCl}_{3}$ complexes in the literature (ca. $-80 \mathrm{ppm}$ in $\left.\mathrm{CDCl}_{3}\right) \cdot{ }^{100-102}$ This reflects that $\left[\mathrm{OAc}^{\mathrm{F}}\right]^{-}$is a weaker trans influence ligand than $\mathrm{Cl}^{-}$, being consistent with reported experimental and computational data for the trans influence of carboxylate ligands $v s$. chloride ligands in square planar complexes. ${ }^{103-105}$

To further evaluate the effect of the identity of the ligand trans to nitrogen on the coordination shift of pyridine-N, $\Delta \delta^{15} \mathrm{~N}$ for $2 \mathbf{a}-\mathbf{A u}(\mathbf{O A c})_{2}$ and $2 \mathbf{a}-\mathbf{A u}\left(\mathbf{C H}_{3}\right)_{2}$ were obtained, and compared to the one found for $\mathbf{2 a}-\mathbf{A u}\left(\mathbf{O A c} \mathbf{c}^{\mathbf{F}}\right)_{2}$. For the three complexes, $\Delta \delta^{15} \mathrm{~N}$ was found to decrease in the order $2 \mathbf{a}-\mathbf{A u}$ $\left(\mathbf{O A c}^{\mathbf{F}}\right)_{2} \sim \mathbf{2 a - A u}(\mathbf{O A c})_{2}>\mathbf{2 a - A u}\left(\mathbf{C H}_{3}\right)_{2}$, agreeing with the established trans influence of the corresponding ligands; $\left[\mathrm{OAc}^{\mathrm{F}}\right]^{-} \sim$ $[\mathrm{OAc}]^{-}<\mathrm{CH}_{3}{ }^{-19,103,104}$ Coordination shifts were also obtained

Table $2 \tau_{4}^{\prime}$ values and selected bond lengths (Å) and angles $\left(^{\circ}\right)$ for $(N, C, C) A u($ III) complexes

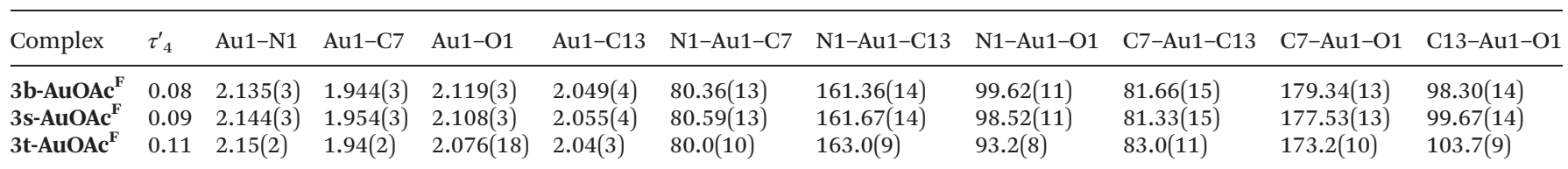

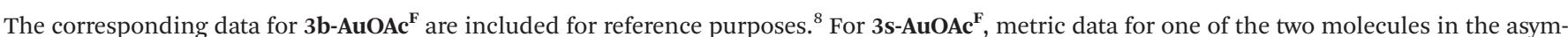
metric unit are listed. See Fig. S160 (ESI) $\dagger$ for metric data for both molecules in the asymmetric unit. For $3 \mathbf{t}-\mathbf{A u O A c} \mathbf{c}^{\mathbf{F}}$, metric data for one of the four molecules in the asymmetric unit are listed. See Fig. S162 (ESI) $\dagger$ for metric data for all molecules in the asymmetric unit. 

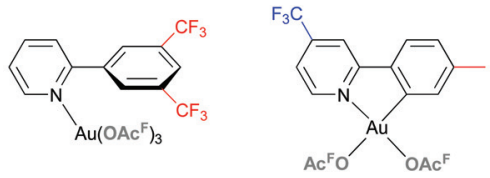

1f-Au(OAc $\left.{ }^{\mathrm{F}}\right)_{3}$ $\delta^{15} \mathrm{~N}=-186.5 \mathrm{ppm}$ $\Delta\left(\delta^{15} \mathrm{~N}\right)=-114.0 \mathrm{ppm}$

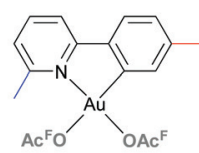

$\delta^{15} \mathrm{~N}=-160.4 \mathrm{ppm}$

$\mathrm{MeO}$

$\left(\delta^{15} \mathrm{~N}\right)=-95.5 \mathrm{ppm}$

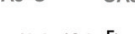

$2 \mathrm{i}-\mathrm{Au}\left(\mathrm{OAc}^{\mathrm{F}}\right)_{2}$
$\delta^{15} \mathrm{~N}=-161.7 \mathrm{ppm}$

$\Delta\left(\delta^{15} \mathrm{~N}\right)=-88.2 \mathrm{ppm}$

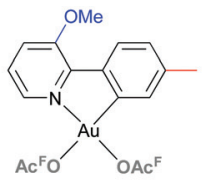

2n-Au( $\left(\mathrm{OAC}^{\mathrm{F}}\right)_{2}$

$\delta^{15} \mathrm{~N}=-164.9 \mathrm{ppm}$

$\Delta\left(\delta^{15} \mathrm{~N}\right)=-101.0 \mathrm{ppm}$
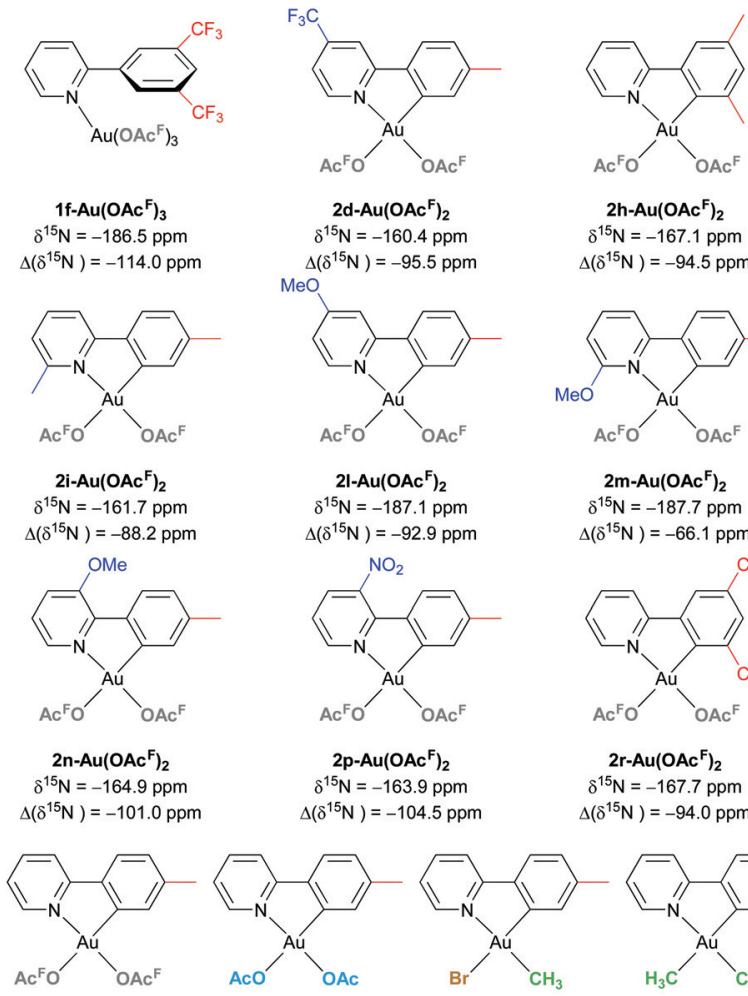

2h-Au(OAc $\left.{ }^{F}\right)_{2}$

$\delta^{15} \mathrm{~N}=-167.1 \mathrm{ppm}$

$\Delta\left(\delta^{15} \mathrm{~N}\right)=-94.5 \mathrm{ppm}$

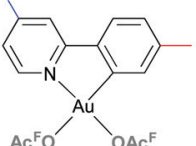

21-Au(OAc $\left.{ }^{F}\right)_{2}$ $\delta^{15} \mathrm{~N}=-187.1 \mathrm{ppm}$ $\Delta\left(\delta^{15} \mathrm{~N}\right)=-92.9 \mathrm{ppm}$

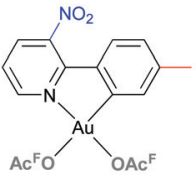

2p-Au $\left(\mathrm{OAc}^{\mathrm{F}}\right)_{2}$ $\delta^{15} \mathrm{~N}=-163.9 \mathrm{ppm}$ $\Delta\left(\delta^{15} \mathrm{~N}\right)=-104.5 \mathrm{ppm}$

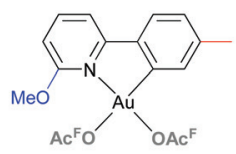

2m-Au(OAc ${ }^{F}$ ) $\delta^{15} \mathrm{~N}=-187.7 \mathrm{ppm}$ $\Delta\left(\delta^{15} \mathrm{~N}\right)=-66.1 \mathrm{ppm}$

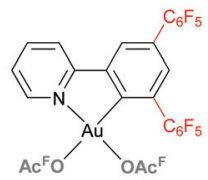

2r-Au(OACF $)_{2}$ $\delta^{15} \mathrm{~N}=-167.7 \mathrm{ppm}$ $\Delta\left(\delta^{15} \mathrm{~N}\right)=-94.0 \mathrm{ppm}$

2a-Au $\left(\mathrm{OAC}^{\mathrm{F}}\right)_{2}$ $\delta^{15} \mathrm{~N}=-165.6 \mathrm{ppm}$ $\Delta\left(\delta^{15} \mathrm{~N}\right)=-90.7 \mathrm{ppm}$

\section{2a-Au(OAc) $\delta^{15} \mathrm{~N}=-164.4 \mathrm{ppm}$} $\Delta\left(\delta^{15} \mathrm{~N}\right)=-89.5 \mathrm{ppm}$

2a-Au( $\left.\mathrm{CH}_{3}\right) \mathrm{Br}$ $\delta^{15} \mathrm{~N}=-121.6 \mathrm{ppm}$ $\Delta\left(\delta^{15} \mathrm{~N}\right)=-46.7 \mathrm{ppm}$

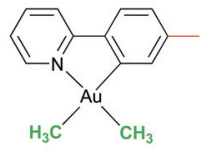

2a-Au $\left(\mathrm{CH}_{3}\right)_{2}$ $\delta^{15} \mathrm{~N}=-131.0 \mathrm{ppm}$ $\Delta\left(\delta^{15} \mathrm{~N}\right)=-56.1 \mathrm{ppm}$

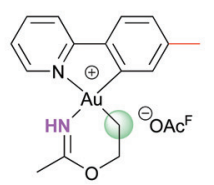

[2a-Au(C,N)] ${ }^{+}\left[\mathrm{OAc}^{\mathrm{F}}\right]^{-}$

$\delta^{15} \mathrm{~N}=-129.0 \mathrm{ppm}$ $\Delta\left(\delta^{15} \mathrm{~N}\right)=-54.1 \mathrm{ppm}$

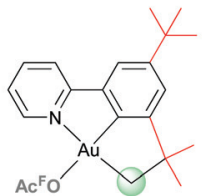

3b-AuOAc ${ }^{F}$

$\delta^{15} \mathrm{~N}=-111.6 \mathrm{ppm}$

$\Delta\left(\delta^{15} \mathrm{~N}\right)=-39.2 \mathrm{ppm}$

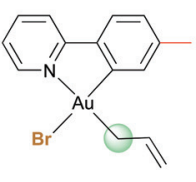

2a-Au $\left(\mathrm{CH}_{2} \mathrm{CH}=\mathrm{CH}_{2}\right) \mathrm{Br}$ $\delta^{15} \mathrm{~N}=-122.6 \mathrm{ppm}$ $\Delta\left(\delta^{15} \mathrm{~N}\right)=-47.7 \mathrm{ppm}$

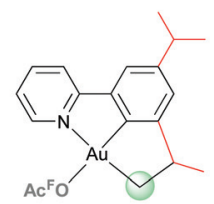

3s-AUOACF $\delta^{15} \mathrm{~N}=-111.7 \mathrm{ppm}$ $\Delta\left(\delta^{15} \mathrm{~N}\right)=-38.1 \mathrm{ppm}$

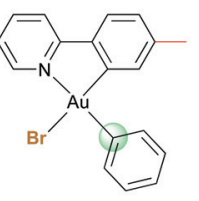

2a-Au $\left(\mathrm{C}_{6} \mathrm{H}_{5}\right) \mathrm{Br}$ $\delta^{15} \mathrm{~N}=-127.9 \mathrm{ppm}$ $\Delta\left(\delta^{15} \mathrm{~N}\right)=-53.0 \mathrm{ppm}$

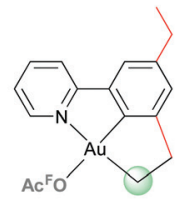

3t-AuOAc ${ }^{F}$ $\delta^{15} \mathrm{~N}=-110.7 \mathrm{ppm}$ $\Delta\left(\delta^{15} \mathrm{~N}\right)=-37.1 \mathrm{ppm}$
Fig. 6 Overview of $(\mathrm{N}, \mathrm{C})$ and $(\mathrm{N}, \mathrm{C}, \mathrm{C}) \mathrm{Au}(\mathrm{III})$ complexes studied by ${ }^{15} \mathrm{~N}$ NMR spectroscopy herein. All data were collected in $\mathrm{CD}_{2} \mathrm{Cl}_{2}$ at either 600 or $800 \mathrm{MHz}$. See also Table S1, ESI. $\dagger \delta^{15} \mathrm{~N}$ for $[2 \mathrm{a}-\mathrm{Au}(\mathrm{C}, \mathrm{N})]^{+}\left[\mathrm{OAc}^{\mathrm{F}}\right]^{-}$ is from ref. 25 .

for the pincer complexes $\mathbf{3 b - A u O A c} \mathbf{c}^{\mathbf{F}}, \mathbf{3 s - \mathbf { A u O A c }} \mathbf{c}^{\mathbf{F}}$ and $\mathbf{3 t - A \mathbf { A O A c }} \mathbf{c}^{\mathbf{F}}$ which all have an alkyl group trans to pyridine-N. As expected from the differences in relative trans influence strength of an alkyl ligand and a $\left[\mathrm{OAc}^{\mathrm{F}}\right]^{-}$ligand, the coordination shifts for the three pincers were significantly smaller $\left(\Delta \delta^{15} \mathrm{~N}\right.$ from -37.1 to $-39.5 \mathrm{ppm}$ ) than those obtained for the di(trifluoroacetate) complexes. Surprisingly, they were also found to be smaller than the coordination shifts of $2 \mathbf{a}-\mathbf{A u}\left(\mathbf{C H}_{3}\right)_{2}, \quad \mathbf{2 a}-\mathbf{A u}$ $\left(\mathrm{CH}_{2} \mathbf{C H}=\mathrm{CH}_{2}\right) \mathrm{Br}, \quad 2 \mathrm{a}-\mathrm{Au}\left(\mathrm{CH}_{3}\right) \mathrm{Br}$ and $[2 \mathrm{a}-\mathrm{Au}(\mathrm{C}, \mathbf{N})]^{+}\left[\mathrm{OAc}^{\mathrm{F}}\right]^{-}$, although it could be anticipated that the relative trans influence of the ligands trans to pyridine-N would be similar for all these complexes. The observations may be explained from differences in the relative cis influence of an alkyl ligand, a halide ligand and a carboxylate ligand. A smaller $\Delta \delta^{15} \mathrm{~N}$ was found for $2 \mathbf{a}-\mathbf{A u}\left(\mathbf{C H}_{3}\right) \mathbf{B r}\left(\Delta \delta^{15} \mathrm{~N}=-46.7 \mathrm{ppm}\right)$ compared to $2 \mathrm{a}$ $\mathbf{A u}\left(\mathbf{C H}_{3}\right)_{2}\left(\Delta \delta^{15} \mathrm{~N}=-56.1 \mathrm{ppm}\right)$ being in accordance with the reported higher cis influence of halide ligands compared to alkyl ligands. ${ }^{106,107}$ In summary, the findings from the ${ }^{15} \mathrm{~N}$ NMR spectroscopic studies show that functionalization of the ligand backbone has little effect on the interaction between pyridine-N and gold, whereas the nature of the ligands cis and trans to pyridine-N has a significantly larger effect.

\section{DFT calculations on the formation of (N,C,C)-cyclometalated} $\mathrm{Au}(\mathrm{III})$ complexes 3s-AuOAc ${ }^{\mathrm{F}}$ and $3 \mathrm{t}-\mathrm{AuOAc}^{\mathrm{F}}$

In order to gain understanding of pincer formation for tridentate (N,C,C) ligands 1s and 1t, DFT calculations were performed. The formation of $\mathbf{3 s - A u O A c} \mathbf{c}^{\mathbf{F}}$ and $\mathbf{3 t - A u O A c} \mathbf{c}^{\mathbf{F}}$ starting from complexes $\mathbf{2 s - A u}\left(\mathbf{O A c} c^{\mathbf{F}}\right)_{2}$ and $\mathbf{2 t - A u}\left(\mathbf{O A c} \mathbf{c}^{\mathbf{F}}\right)_{2}$ via the same mechanism proposed for the formation of $3 \mathbf{b}-\mathbf{A u O A c} \mathbf{c}^{\mathbf{8}}$ was explored (Fig. 7). As the formation of $2 \mathbf{s}-\mathbf{A u}\left(\mathbf{O A c} \mathbf{c}^{\mathbf{F}}\right)_{2}$ was found to be very similar to that of $\mathbf{2 b}-\mathbf{A u}\left(\mathbf{O A c} \mathbf{c}^{\mathbf{F}}\right)_{2}$, the energies for this first cyclometalation step are not included in the figure (see Table S17, ESI $\dagger$ for details), and was not calculated for $\mathbf{2 t - A u}$ $\left(\mathrm{OAc}^{\mathrm{F}}\right)_{2}$.

Looking at the $\mathrm{C}-\mathrm{H}$ activation step, a clear difference in energy for TS1 was observed for the three complexes, illustrating the effect of the substituent on the formation of the desired pincer complex. The endergonic dissociation step

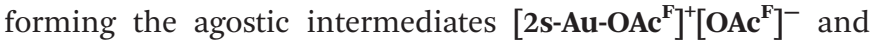
$[\mathbf{2 t - A u - O A c}]^{+}\left[\mathbf{O A c}^{\mathbf{F}}\right]^{-}$is more than $10 \mathrm{kcal} \mathrm{mol}^{-1}$ higher in

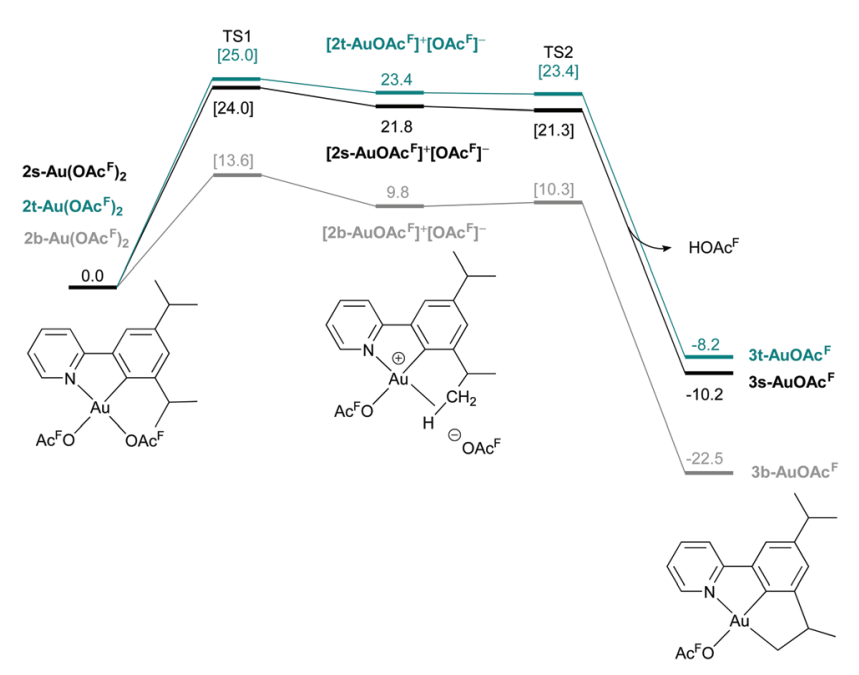

Fig. 7 Free energy profile in kcal $\mathrm{mol}^{-1}$ for the formation of $3 b$ $A u O A c^{F}, 3 s-A u O A c^{F}$ and $3 t-A u O A c^{F}$ from the corresponding di(trifluoroacetate) complexes. In the figure, $2 s-A u\left(O A c^{F}\right)_{2},\left[2 s-A u O A c^{F}\right]^{+}\left[O A c^{F}\right]^{-}$ and $3 \mathrm{~s}-\mathrm{AuOAc} \mathrm{F}^{\mathrm{F}}$ are displayed as structural examples. The energies of all minima and transition states in brackets are computed in $\mathrm{CH}_{2} \mathrm{Cl}_{2}$ (SMD) for $3 s-A u O A c^{F}$ and $3 t-A u O A c^{F}$. The energies and transition states for $3 b-$ AuOAc ${ }^{\mathrm{F}}$ were computed in $\mathrm{HOAC}^{\mathrm{F}}$. 


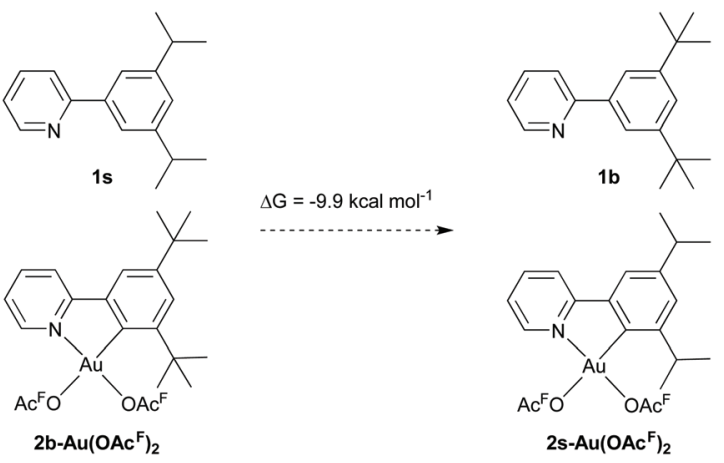

Scheme 8 Isodesmic reaction for the formal chelate ligand exchange on $2 b-A u\left(O A c^{F}\right)_{2}$ furnishing $2 s-A u\left(O A c^{F}\right)_{2}$. Gibbs energy in $\mathrm{CH}_{2} \mathrm{Cl}_{2}(\mathrm{SMD})$ is given in $\mathrm{kcal} \mathrm{mol}^{-1}$.

energy for $\mathbf{3 s - A u O A c}{ }^{\mathbf{F}}$ and $\mathbf{3 t}-\mathbf{A u O A c} \mathbf{F}^{\mathbf{F}}\left(24.0 \mathrm{kcal} \mathrm{mol}^{-1}\right.$ and $25.0 \mathrm{kcal} \mathrm{mol}^{-1}$, respectively), compared to $3 \mathbf{b}-\mathbf{A u O A c} \mathbf{c}^{\mathbf{F}}$ $\left(13.6 \mathrm{kcal} \mathrm{mol}^{-1}\right)$. The following proton abstractions by $\left[\mathrm{OAc}^{\mathrm{F}}\right]^{-}$ that furnish $\mathbf{3 s - A u O A c} \mathbf{c}^{\mathbf{F}}$ and $\mathbf{3 t - A u O A c} \mathbf{c}^{\mathbf{F}}$ are barrier-free, which is in accordance with what was found for $\mathbf{3 b} \mathbf{b}-\mathbf{A u O A c} \mathbf{C}^{\mathbf{F}}$.

The energy barrier associated with the formation of the agostic intermediates is depending on the bulkiness of the alkyl substituent that undergoes $\mathrm{C}-\mathrm{H}$ activation. The lower energy barrier for $\left[\mathbf{2} \mathbf{b}-\mathbf{A u}-\mathbf{O A} \mathbf{c}^{\mathbf{F}}\right]^{+}\left[\mathbf{O A} \mathbf{c}^{\mathbf{F}}\right]^{-}$is due to the higher

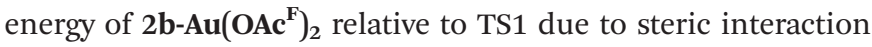
with the tert-butyl group in the (N,C)-cyclometalated complex. In order to highlight the difference in stability of the (N,C)cyclometalated complexes $2 \mathbf{b}-\mathbf{A u}\left(\mathbf{O A c}{ }^{\mathbf{F}}\right)_{2}$ and e.g. $\left.2 \mathbf{s}-\mathbf{A u}(\mathbf{O A c})_{2}\right)_{2}$, which is responsible for the significantly lower TS1 found for the tert-butyl system, an isodesmic reaction of a formal chelate ligand exchange on $\mathbf{2 b}-\mathbf{A u}\left(\mathbf{O A} \mathbf{c}^{\mathbf{F}}\right)_{2}$ with $\mathbf{1 s}$ was investigated (Scheme 8). The formation of $2 \mathbf{s}-\mathbf{A u}\left(\mathbf{O A c}^{\mathbf{F}}\right)_{2}$ and $\mathbf{1 b}$ is favoured by $9.9 \mathrm{kcal} \mathrm{mol}^{-1}$ which illustrates the negative effect the large, bulky substituents have on the stability of di(trifluoroacetate) complexes. On the other hand, this characteristic of the tertbutyl substituent ultimately facilitates the $\mathrm{C}\left(\mathrm{sp}^{3}\right)-\mathrm{H}$ bond activation step and subsequent pincer formation.

\section{Conclusions}

In this work, a detailed experimental and computational study of a series of 2-arylpyridine-based (N,C)- and (N,C,C)-cyclometalated $\mathrm{Au}(\mathrm{III})$ complexes has been presented. For the $(\mathrm{N}, \mathrm{C})$ systems, it was found that the scope of microwave-mediated synthesis of cyclometalated $\mathrm{Au}(\mathrm{III})$ complexes is broad and that a large variety of different functional groups is tolerated. This makes it an attractive method for the synthesis of Au(III) complexes of substituted arylpyridine ligands without having to resort to any organomercury intermediates. The efficiency of the reaction is strongly dependent on the electronic features of the $(\mathrm{N}, \mathrm{C})$ ligand, being consistent with an electrophilic aromatic substitution-type mechanism for cyclometalation at $\mathrm{Au}$ (III). Natural charge analysis performed on the protonated ( $\mathrm{N}$, C) ligands was found to correlate with the experimental obser- vations of their reactivity towards $\mathrm{Au}(\mathrm{OAc})_{3}$. Single-crystal X-ray diffraction and ${ }^{15} \mathrm{~N}$ NMR spectroscopy data suggest that the (N,C) $\mathrm{Au}(\mathrm{III})$ complexes are structurally similar species, meaning that the ligand scaffold is flexible to changes without drastically affecting the coordination sphere around $\mathrm{Au}$. Detailed ${ }^{15} \mathrm{~N}$ NMR spectroscopic studies of different cyclometalated $\mathrm{Au}(\mathrm{III})$ complexes with varying ligands trans to the $(\mathrm{N}, \mathrm{C})$ backbone show that these ligands have a much stronger influence on the $\mathrm{Au}-\mathrm{N}$ interaction than any substituents in the backbone, with the exception of the 6-methoxy-substituted complex 2m-Au( $\left(\mathbf{O A c}^{\mathbf{F}}\right)_{2}$. For this complex, the relatively small coordination shift may be explained by a possible weak interaction between the methoxy-oxygen and gold. In addition to the studies of (N,C)-cyclometalated $\mathrm{Au}(\mathrm{III})$ complexes, $\mathrm{C}\left(\mathrm{sp}^{3}\right)-\mathrm{H}$ bond activation as a synthetic feasible method to yield (N,C,C)cyclometalated $\mathrm{Au}(\mathrm{III})$ complexes was expanded. Earlier we have shown that the ligand 2-(3,5-di-tert-butylphenyl)pyridine (1b) functions as a tridentate ligand for $\mathrm{Au}(\mathrm{III})$, yielding pincer complex $\mathbf{3 b} \mathbf{b}-\mathbf{A u O A c} \mathbf{c}^{\mathbf{F}}$. We have broadened the scope of $\mathrm{Au}$ (III) pincer formation, via $\mathrm{C}\left(\mathrm{sp}^{3}\right)-\mathrm{H}$ bond activation to include less sterically encumbered ligands. These ligands contain either isopropyl (1s) or ethyl (1t and 1u) groups, where the $\mathrm{C}-\mathrm{H}$ bond that is activated is able to rotate away from gold. In a combined experimental and computational effort we have shown that these ligands indeed undergo $\mathrm{C}\left(\mathrm{sp}^{3}\right)-\mathrm{H}$ bond activation, but that the process is less facile than for the tert-butyl-substituted system. Further work will focus on broadening the scope of (N,C,C) pincer formation from alkyl-substituted 2-arylpyridines, as well as investigating their reactivity and optical properties.

\section{Experimental section}

\section{General considerations}

$2 \mathrm{a}-\mathrm{Au}\left(\mathrm{OAc}^{\mathrm{F}}\right)_{2},{ }^{19} \quad 3 \mathbf{b}-\mathbf{A u O A c}{ }^{\mathrm{F}},{ }^{8} \quad \mathbf{2 a - A u}(\mathrm{OAc})_{2},{ }^{14,95} \quad \mathbf{2 a - A u}$ $\left(\mathbf{C H}_{2} \mathbf{C H}=\mathbf{C H}_{2}\right) \mathrm{Br}^{22}{ }^{22} \mathbf{a}-\mathrm{Au}\left(\mathrm{C}_{6} \mathbf{H}_{5}\right) \mathbf{B r},{ }^{19} 2 \mathrm{a}-\mathrm{Au}\left(\mathrm{CH}_{3}\right) \mathbf{B r},{ }^{19}$ 2a-Au $\left(\mathbf{C H}_{3}\right)_{2}{ }^{19}$ 3,5-diethylphenylboronic acid $^{108,109}$ and 3,5-diisopropylphenylboronic acid ${ }^{108,109}$ were synthesized according to literature procedures. $\mathrm{Au}(\mathrm{OAc})_{3}$ was obtained from abcr. THF (unstabilized) and $\mathrm{CH}_{2} \mathrm{Cl}_{2}$ were dried using an MB SPS-800 solvent purifier system from MBraun. Hexanes and ethyl acetate were distilled before use. Deionized water was used. Other chemicals and solvents were used as received from commercial sources. TLC was performed using Merck 60 F254 plates. Flash chromatography was performed using silica gel from Merck (60, 0.040-0.063 mm). Microwave reactions were performed with a Milestone MicroSYNTH microwave reactor with a SK-10 rotor or, for reaction volumes smaller than $10 \mathrm{~mL}$, in an Anton Paar $\mathrm{GmbH}$ Monowave 300 synthesis reactor equipped with an internal IR probe calibrated with a Ruby thermometer. NMR spectroscopy was performed using Bruker Avance DPX300, AVII400, AVIIIHD400, DRX500, AVI600, AVII600 or AVIIIHD800 operating at $300 \mathrm{MHz}\left({ }^{1} \mathrm{H} \mathrm{NMR}\right)$, or $400 \mathrm{MHz}\left({ }^{1} \mathrm{H}\right.$ NMR), $376 \mathrm{MHz}\left({ }^{19} \mathrm{~F}\right.$ NMR $), 101 \mathrm{MHz}\left({ }^{13} \mathrm{C} \mathrm{NMR}\right)$, or $500 \mathrm{MHz}\left({ }^{1} \mathrm{H} \mathrm{NMR}\right)$, or $600 \mathrm{MHz}\left({ }^{1} \mathrm{H}\right.$ NMR) and $151 \mathrm{MHz}$ 


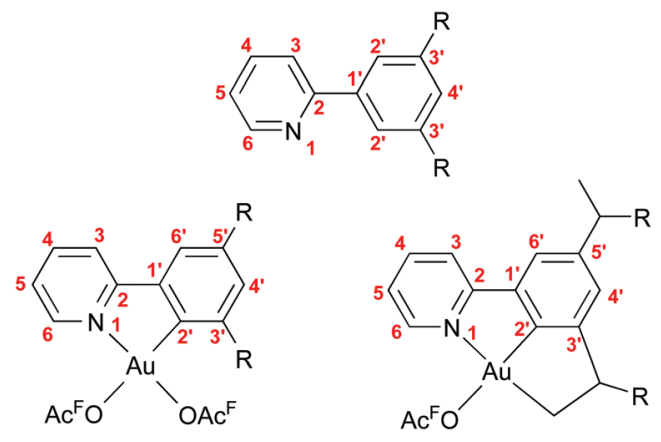

Fig. 8 Numbering scheme used for reporting the NMR data.

$\left({ }^{13} \mathrm{C}\right.$ NMR $)$, or $800 \mathrm{MHz}\left({ }^{1} \mathrm{H}\right.$ NMR $)$ and $201 \mathrm{MHz}\left({ }^{13} \mathrm{C}\right.$ NMR $)$ respectively. All spectra were recorded at room temperature. ${ }^{1} \mathrm{H}$ NMR and ${ }^{13} \mathrm{C}$ NMR spectra have been referenced relative to the residual solvent signals, and the resonances are numbered according to Fig. 8. Chemical shifts in ${ }^{19} \mathrm{~F}$ NMR have been referenced to $\mathrm{CFCl}_{3}$ by using $\mathrm{C}_{6} \mathrm{~F}_{6}$ or $\mathrm{C}_{6} \mathrm{H}_{5} \mathrm{~F}(-164.9 \mathrm{ppm}$ and $-116.1 \mathrm{ppm}$ with respect to $\mathrm{CFCl}_{3}$ at $\left.0 \mathrm{ppm}\right)$ as an internal standard, and are proton decoupled. Chemical shifts in ${ }^{15} \mathrm{~N}$ NMR have been calibrated against $\mathrm{CH}_{3} \mathrm{NO}_{2}$ as an external standard $(0.0 \mathrm{ppm})$. All ${ }^{15} \mathrm{~N}$ NMR chemical shifts were obtained and assigned using ${ }^{1} \mathrm{H}^{-15} \mathrm{~N}$ HMBC experiments. The resonances in the ${ }^{1} \mathrm{H}$ NMR and ${ }^{13} \mathrm{C}$ NMR spectra were assigned using various 2D experiments (COSY, NOESY, HSQC and HMBC). MS (ESI and APPI) was recorded on a Bruker maXis II ETD spectrometer. All melting points are uncorrected and were obtained with a Stuart SMP10 melting point apparatus. Elemental analysis was performed by Mikroanalytisches Laboratorium Kolbe, Oberhausen, Germany. Single-crystal diffraction data were acquired on a Bruker D8 Venture equipped with a Photon $100 \mathrm{CMOS}$ area detector, and using Mo $\mathrm{K} \alpha$ radiation $(\lambda=0.71073 \AA)$ or $\mathrm{Cu} \mathrm{K} \alpha$ radiation $(\lambda=$ $1.5406 \AA$ ) from an Incoatec i $\mu \mathrm{S}$ microsource. Data reduction was performed with the Bruker Apex3 Suite, the structures were solved with ShelXT ${ }^{110}$ and refined with ShelXL. ${ }^{111}$ Olex2 was used as user interface. ${ }^{112}$ The cif files were edited with enCIFer v. 1.4. ${ }^{113}$ Full details of the data collection, structure solution and refinement for each compound are contained in the cif files, available from https://www.ccdc.cam.ac.uk/(CCDC $2115512\left(2 \mathbf{c}-\mathbf{A u}\left(\mathbf{O A c}^{\mathrm{F}}\right)_{2}\right), 2122527\left(\mathbf{2 d - A u}\left(\mathbf{O A c}^{\mathrm{F}}\right)_{2}\right), 2085151(2 \mathrm{e}-$ $\left.\mathbf{A u}\left(\mathbf{O A c}^{\mathbf{F}}\right)_{2}\right), 2086346\left(\mathbf{2 h}-\mathbf{A u}\left(\mathbf{O A c}^{\mathrm{F}}\right)_{2}\right), 2126159\left(\mathbf{2 i - A u}\left(\mathbf{O A c}^{\mathrm{F}}\right)_{2}\right)$, $2126283\left(2 \mathbf{j}_{3} \mathbf{A u}_{2}\left(\mathbf{O A c}^{\mathrm{F}}\right)_{2}\right), 2122284\left(2 \mathbf{l}-\mathbf{A u}\left(\mathbf{O A c}^{\mathrm{F}}\right)_{2}\right), 2111917(2 \mathbf{m}-$ $\left.\mathbf{A u}\left(\mathbf{O A c}^{\mathrm{F}}\right)_{2}\right), 2105655\left(\mathbf{2 n - A u}\left(\mathbf{O A c}^{\mathrm{F}}\right)_{2}\right), 2086931\left(\mathbf{2 o - A u}\left(\mathbf{O A c}^{\mathrm{F}}\right)_{2}\right)$, $2126114\left(2 \mathbf{p}-\mathbf{A u}\left(\mathbf{O A c}^{\mathrm{F}}\right)_{2}\right), 2130186\left(\mathbf{2 r - A u}\left(\mathbf{O A c}^{\mathrm{F}}\right)_{2}\right), 2126097$ (3s$\left.\mathbf{A u O A c}^{\mathbf{F}}\right)$ and $\left.2114274\left(3 \mathbf{t}-\mathbf{A u O A c}^{\mathbf{F}}\right)\right)$. The data are summarized in Tables S2-S15, ESI. $\dagger$

Experimental and analytical data for a selection of compounds described within the text are presented here, data for all compounds can be found in the ESI. $\dagger$

\section{General procedure for synthesis of arylpyridine ligands}

2-Bromopyridine or substituted 2-bromopyridine $(5.00 \mathrm{mmol}$, 1.0 equiv.) and arylboronic acid (4.75-5.50 mmol, 0.95-1.1 equiv.) were dissolved in $n$-PrOH $(10 \mathrm{~mL})$. A solution of $\mathrm{K}_{3} \mathrm{PO}_{4}$ (10.0-11.5 mmol, 2.0-2.3 equiv.) in water $(10 \mathrm{~mL})$ was added, and the resulting biphasic mixture was degassed for $10 \mathrm{~min}$ by bubbling Ar through it. $\mathrm{Pd}(\mathrm{OAc})_{2}(0.100 \mathrm{mmol}, 2.0 \mathrm{~mol} \%)$ and $\mathrm{PPh}_{3}(0.300 \mathrm{mmol}, 6.0 \mathrm{~mol} \%)$ were added, and the reaction mixture was heated at reflux temperature for $3 \mathrm{~h}$ under Ar. After cooling to $\mathrm{rt}, \mathrm{CH}_{2} \mathrm{Cl}_{2}(50 \mathrm{~mL})$ and water $(50 \mathrm{~mL})$ were added. The phases were separated, and the $\mathrm{CH}_{2} \mathrm{Cl}_{2}$ solution was washed with $2 \mathrm{M} \mathrm{NaOH}(\mathrm{aq})(2 \times 50 \mathrm{~mL})$, brine $(50 \mathrm{~mL})$, and was dried over $\mathrm{Na}_{2} \mathrm{SO}_{4}$. The solvent was removed under reduced pressure. The obtained residue was purified by flash column chromatography (hexanes/EtOAc, hexanes $/ \mathrm{CH}_{2} \mathrm{Cl}_{2}$ or hexanes/EtOAc/ $\mathrm{CH}_{2} \mathrm{Cl}_{2}$ mixtures), furnishing the arylpyridine ligand.

2-(3,5-Difluorophenyl)pyridine (1c). The general procedure was followed. 2-Bromopyridine $(0.789 \mathrm{~g}, 4.99 \mathrm{mmol}, 1.0$ equiv.), 3,5-difluorophenylboronic acid $(0.866 \mathrm{~g}, 5.48 \mathrm{mmol}$, 1.1 equiv.), $\mathrm{K}_{3} \mathrm{PO}_{4}\left(2.14 \mathrm{~g}, 10.1 \mathrm{mmol}, 2.0\right.$ equiv.), $\mathrm{Pd}(\mathrm{OAc})_{2}$ (0.0236 g, $0.105 \mathrm{mmol}, 2.1 \mathrm{~mol} \%)$ and $\mathrm{PPh}_{3}(0.0808 \mathrm{~g}$, $0.308 \mathrm{mmol}, 6.2 \mathrm{~mol} \%$ ) were used. The crude product was purified by flash column chromatography (98\% hexanes/2\% EtOAc as eluent to $95 \%$ hexanes/5\% EtOAc) yielding $1 \mathrm{c}$ as a colourless solid (0.870 g, $4.55 \mathrm{mmol}, 91 \%)$. Mp. 61-62 ${ }^{\circ} \mathrm{C} .{ }^{1} \mathrm{H}$ $\operatorname{NMR}\left(600 \mathrm{MHz}, \mathrm{CDCl}_{3}\right): \delta 8.70\left(\mathrm{~d},{ }^{3} J_{\mathrm{H}, \mathrm{H}}=4.8 \mathrm{~Hz}, 1 \mathrm{H}, \mathrm{H}^{6}\right), 7.78$ (ddd, ${ }^{3} J_{\mathrm{H}, \mathrm{H}}=7.8 \mathrm{~Hz},{ }^{3} J_{\mathrm{H}, \mathrm{H}}=7.7 \mathrm{~Hz},{ }^{4} J_{\mathrm{H}, \mathrm{H}}=1.8 \mathrm{~Hz}, 1 \mathrm{H}, \mathrm{H}^{4}$ ), $7.69\left(\mathrm{~d},{ }^{3} J_{\mathrm{H}, \mathrm{H}}=7.9 \mathrm{~Hz}, 1 \mathrm{H}, \mathrm{H}^{3}\right), 7.53-7.57\left(\mathrm{~m}, 2 \mathrm{H}, \mathrm{H}^{2}\right), 7.29$ (ddd, ${ }^{3} J_{\mathrm{H}, \mathrm{H}}=7.4 \mathrm{~Hz},{ }^{3} J_{\mathrm{H}, \mathrm{H}}=4.8 \mathrm{~Hz},{ }^{4} J_{\mathrm{H}, \mathrm{H}}=0.9 \mathrm{~Hz}, 1 \mathrm{H}, \mathrm{H}^{5}$ ), $6.85 \mathrm{ppm}\left(\mathrm{m}, 1 \mathrm{H}, \mathrm{H}^{4^{4}}\right) .{ }^{13} \mathrm{C}$ NMR (151 $\left.\mathrm{MHz}, \mathrm{CDCl}_{3}\right): \delta 163.4$ $\left(\mathrm{dd},{ }^{1} J_{\mathrm{C}, \mathrm{F}}=248.1 \mathrm{~Hz},{ }^{3} J_{\mathrm{C}, \mathrm{F}}=12.4 \mathrm{~Hz}, \mathrm{C}^{3}\right), 154.8\left(\mathrm{t},{ }^{4} J_{\mathrm{C}, \mathrm{F}}=2.8\right.$ $\left.\mathrm{Hz}, \mathrm{C}^{2}\right) 149.8\left(\mathrm{C}^{6}\right), 142.7\left(\mathrm{t},{ }^{3} J_{\mathrm{C}, \mathrm{F}}=9.3 \mathrm{~Hz}, \mathrm{C}^{1}\right), 137.0\left(\mathrm{C}^{4}\right), 123.2$ $\left(\mathrm{C}^{5}\right), 120.5\left(\mathrm{C}^{3}\right), 109.6-109.8\left(\mathrm{~m}, \mathrm{C}^{2^{\prime}}\right), 104.1 \mathrm{ppm}\left(\mathrm{t},{ }^{2} J_{\mathrm{C}, \mathrm{F}}=25.7\right.$ $\left.\mathrm{Hz}, \mathrm{C}^{4}\right) .{ }^{19} \mathrm{~F}$ NMR $\left(376 \mathrm{MHz}, \mathrm{CDCl}_{3}\right): \delta-112.8 \mathrm{ppm}(\mathrm{Ar}-\mathrm{F}) .{ }^{15} \mathrm{~N}$ $\left({ }^{1} \mathrm{H}\right)$ NMR $\left(600 \mathrm{MHz}, \mathrm{CDCl}_{3}\right): \delta-72.2 \mathrm{ppm}\left(\mathrm{N}^{1}\right)$. MS (ESI): $\mathrm{m} / \mathrm{z}$ (rel. \%): 192.062 (100) [M + H] $]^{+}$. HRMS (ESI): Found 192.0619. Calc. for $\mathrm{C}_{11} \mathrm{H}_{8} \mathrm{~F}_{2} \mathrm{~N}$ : 192.0619. The NMR data are in accordance with those reported in the literature. ${ }^{114}$

6-Methoxy-2-(4-methylphenyl)pyridine (1m). The general procedure was followed. 2-Bromo-6-methoxypyridine $(0.803 \mathrm{~g}$, $4.27 \mathrm{mmol}, 1.0$ equiv.), 4-methylphenylboronic acid (0.638 g, $4.69 \mathrm{mmol}, 1.1$ equiv.), $\mathrm{K}_{3} \mathrm{PO}_{4}(2.12 \mathrm{~g}, 10.0 \mathrm{mmol}, 2.3$ equiv.), $\mathrm{Pd}(\mathrm{OAc})_{2}(0.0187 \mathrm{~g}, 0.0883 \mathrm{mmol}, 2.0 \mathrm{~mol} \%)$ and $\mathrm{PPh}_{3}$ (0.0664 g, $0.253 \mathrm{mmol}, 5.9 \mathrm{~mol} \%)$ were used. The obtained crude product was purified by flash column chromatography (98\% hexanes/2\% EtOAc), furnishing $\mathbf{1 m}$ as a colourless oil (0.697 g, $3.50 \mathrm{mmol}, 82 \%) .{ }^{1} \mathrm{H}$ NMR $\left(400 \mathrm{MHz}, \mathrm{CDCl}_{3}\right): \delta 7.95$ $\left(\mathrm{d},{ }^{3} J_{\mathrm{H}, \mathrm{H}}=8.2 \mathrm{~Hz}, 2 \mathrm{H}, \mathrm{H}^{2}\right), 7.59-7.63\left(\mathrm{~m}, 1 \mathrm{H}, \mathrm{H}^{4}\right), 7.32\left(\mathrm{~d},{ }^{3} J_{\mathrm{H}, \mathrm{H}}\right.$ $\left.=7.4 \mathrm{~Hz}, 1 \mathrm{H}, \mathrm{H}^{3}\right), 7.25-7.28(\mathrm{~m}$ (partially overlap with the resonance corresponding to residual $\left.\left.\mathrm{CHCl}_{3}\right), 2 \mathrm{H}, \mathrm{H}^{3}\right), 6.66(\mathrm{~d}$, $\left.{ }^{3} J_{\mathrm{H}, \mathrm{H}}=8.2 \mathrm{~Hz}, 1 \mathrm{H}, \mathrm{H}^{5}\right), 4.04\left(\mathrm{~s}, 3 \mathrm{H}, \mathrm{OCH}_{3}\right), 2.41 \mathrm{ppm}(\mathrm{s}, 3 \mathrm{H}$, $\left.\mathrm{Ar}-\mathrm{CH}_{3}\right) .{ }^{13} \mathrm{C}$ NMR $\left(101 \mathrm{MHz}, \mathrm{CDCl}_{3}\right): \delta 163.6\left(\mathrm{C}^{6}\right), 154.7\left(\mathrm{C}^{2}\right)$, $139.07\left(\mathrm{C}^{4}\right), 138.77\left(\mathrm{C}^{4^{\prime}}\right), 136.3\left(\mathrm{C}^{1^{\prime}}\right), 129.3\left(\mathrm{C}^{3^{\prime}}\right), 126.6\left(\mathrm{C}^{2}\right)$, 112.4 $\left(\mathrm{C}^{3}\right), 108.8\left(\mathrm{C}^{5}\right), 53.1\left(\mathrm{OCH}_{3}\right), 21.2 \mathrm{ppm}\left(\mathrm{Ar}-\mathrm{CH}_{3}\right) \cdot{ }^{15} \mathrm{~N}\left\{{ }^{1} \mathrm{H}\right\}$ NMR (600 MHz, $\left.\mathrm{CD}_{2} \mathrm{Cl}_{2}\right): \delta-121.5 \mathrm{ppm}\left(\mathrm{N}^{1}\right)$. MS (ESI): $m / z$ (rel. \%): 222.089 (100) [M + Na] $]^{+}$. HRMS (ESI): Found 222.0887. Calc. for $\mathrm{C}_{13} \mathrm{H}_{13} \mathrm{NNaO}$ : 222.0889. The NMR data are in accordance with those reported in the literature. ${ }^{115}$ 
2-(2,2",3,3",4,4",5,5",6,6"-Decafluoro-[1,1':3',1"-terphenyl]-5'yl)pyridine (1r). The synthesis of $\mathbf{1 r}$ was adapted from a literature procedure. ${ }^{71} \mathrm{~K}_{2} \mathrm{CO}_{3}$ (1.11 g, $8.00 \mathrm{mmol}, 4.0$ equiv.), $\mathrm{Pd}$ $(\mathrm{OAc})_{2}(0.0225 \mathrm{~g}, 0.100 \mathrm{mmol}, 5.0 \mathrm{~mol} \%)$ and S-Phos $(0.0821 \mathrm{~g}$, $0.200 \mathrm{mmol}, 10 \mathrm{~mol} \%$ ) were added to a Schlenk flask, and flushed with $\mathrm{Ar}$ for $15 \mathrm{~min}$. Pentafluorobenzene $(1.00 \mathrm{~g}$, $6.00 \mathrm{mmol}, 3.0$ equiv.) and $i$-PrOAc $(4 \mathrm{~mL})$ were added, followed by a solution of 16 ( $0.448 \mathrm{~g}, 2.00 \mathrm{mmol}, 1.0$ equiv.) in $i$-PrOAc $(2 \mathrm{~mL})$. After flushing with Ar, the reaction flask was sealed and stirred at $80{ }^{\circ} \mathrm{C}$ for $14 \mathrm{~h}$. After cooling to rt, insoluble material was separated from the reaction mixture by filtration. The solids were washed with additional $i$-PrOAc, and the washings were combined with the original filtrate. The solvent was removed under reduced pressure, and the obtained solid was purified by flash column chromatography (85\% hexanes/15\% EtOAc), followed by two-fold recrystallization from EtOH. 1r was obtained as a colourless fluffy solid (0.356 g, $0.730 \mathrm{mmol}, 37 \%) .{ }^{1} \mathrm{H}$ NMR (600 $\left.\mathrm{MHz}, \mathrm{CDCl}_{3}\right): \delta$ 8.72-8.73 (m, $\left.1 \mathrm{H}, \mathrm{H}^{6}\right), 8.18\left(\mathrm{~s}, 2 \mathrm{H}, \mathrm{H}^{2^{\prime}}\right), 7.78-7.83\left(\mathrm{~m}, 2 \mathrm{H}, \mathrm{H}^{4}+\right.$ $\left.\mathrm{H}^{3}\right), 7.54\left(\mathrm{~s}, 1 \mathrm{H}, \mathrm{H}^{4^{\prime}}\right), 7.31 \mathrm{ppm}\left(\mathrm{ddd},{ }^{3} J_{\mathrm{H}, \mathrm{H}}=7.8 \mathrm{~Hz},{ }^{3} J_{\mathrm{H}, \mathrm{H}}=4.8\right.$ $\left.\mathrm{Hz},{ }^{4} J_{\mathrm{H}, \mathrm{H}}=1.4 \mathrm{~Hz}, 1 \mathrm{H}, \mathrm{H}^{5}\right) .{ }^{13} \mathrm{C} \mathrm{NMR}\left(201 \mathrm{MHz}, \mathrm{CDCl}_{3}\right): \delta$ $155.5\left(\mathrm{C}^{2}\right), 150.0\left(\mathrm{C}^{6}\right), 144.3\left(\mathrm{~d},{ }^{1} J_{\mathrm{C}, \mathrm{F}}=248.5 \mathrm{~Hz}, \mathrm{Ar}-\mathrm{C}-\mathrm{F}\right)$, $140.80\left(\mathrm{~d},{ }^{1} J_{\mathrm{C}, \mathrm{F}}=254.8 \mathrm{~Hz}, \mathrm{Ar}-\mathrm{C}-\mathrm{F}\right), 140.74\left(\mathrm{C}^{1^{\prime}}\right), 137.9\left(\mathrm{~d},{ }^{1} J_{\mathrm{C}, \mathrm{F}}\right.$ $=251.3 \mathrm{~Hz}, \mathrm{Ar}-\mathrm{C}-\mathrm{F}), 137.1\left(\mathrm{C}^{4}\right), 132.0\left(\mathrm{C}^{4^{\prime}}\right), 129.5\left(\mathrm{C}^{2^{\prime}}\right), 127.6$ $\left(\mathrm{C}^{3^{\prime}}\right), 123.0\left(\mathrm{C}^{5}\right), 120.6\left(\mathrm{C}^{3}\right)$, 114.87-115.05 ppm (m, Ar-C-C-F). $\left.{ }^{19} \mathrm{~F} \mathrm{NMR} \mathrm{(376} \mathrm{MHz,} \mathrm{CDCl}_{3}\right): \delta-145.6\left(\mathrm{dd},{ }^{3} J_{\mathrm{F}, \mathrm{F}}=22.6 \mathrm{~Hz},{ }^{4} J_{\mathrm{F}, \mathrm{F}}=\right.$ $\left.6.0 \mathrm{~Hz}, 4 \mathrm{~F}, \mathrm{C}_{6} \mathrm{~F}_{5}\right),-157.4\left(\mathrm{dd},{ }^{3} J_{\mathrm{F}, \mathrm{F}}=21.0 \mathrm{~Hz},{ }^{3} J_{\mathrm{F}, \mathrm{F}}=20.9 \mathrm{~Hz}, 2 \mathrm{~F}\right.$, $\left.\mathrm{C}_{6} \mathrm{~F}_{5}\right),-164.6 \mathrm{ppm}\left(\mathrm{m}, 4 \mathrm{~F}, \mathrm{C}_{6} \mathrm{~F}_{5}\right) .{ }^{15} \mathrm{~N}\left\{{ }^{1} \mathrm{H}\right\}$ NMR $(600 \mathrm{MHz}$, $\mathrm{CD}_{2} \mathrm{Cl}_{2}$ ): $\delta-73.0 \mathrm{ppm}\left(\mathrm{N}^{1}\right)$. MS (ESI): $m / z$ (rel. \%): 510.031 (100) $[\mathrm{M}+\mathrm{Na}]^{+}$. HRMS (ESI): Found 510.0311. Calc. for $\mathrm{C}_{23} \mathrm{H}_{7} \mathrm{~F}_{10} \mathrm{NNa}$ : 510.0311. Elemental analysis: Found: $\mathrm{C}, 56.7 ; \mathrm{H}$, 1.4; N, 2.9. Calc. for $\mathrm{C}_{23} \mathrm{H}_{7} \mathrm{~F}_{10} \mathrm{~N}$ : C, 56.7; H, 1.45; N, 2.9\%.

2-(3,5-Diisopropylphenyl)pyridine (1s). The general procedure was followed. 2-Bromopyridine (0.924 g, $5.85 \mathrm{mmol}, 1.0$ equiv.), 3,5-diisopropylphenylboronic acid (1.20 g, $5.84 \mathrm{mmol}$, 1.0 equiv.), $\mathrm{K}_{3} \mathrm{PO}_{4}$ (2.48 g, $11.7 \mathrm{mmol}, 2.0$ equiv.), $\mathrm{Pd}(\mathrm{OAc})_{2}$ (0.0273 g, $0.122 \mathrm{mmol}, 2.1 \mathrm{~mol} \%)$ and $\mathrm{PPh}_{3}(0.0921 \mathrm{~g}$, $0.352 \mathrm{mmol}, 6.0 \mathrm{~mol} \%$ ) were used. The crude product was purified twice by flash column chromatography (first $85 \%$ hexanes/15\% EtOAc, then $\mathrm{CH}_{2} \mathrm{Cl}_{2}$ ), yielding 1 s as a colourless oil (0.847 g, $3.54 \mathrm{mmol}, 61 \%) .{ }^{1} \mathrm{H}$ NMR (600 $\left.\mathrm{MHz}, \mathrm{CDCl}_{3}\right): \delta$ $8.70\left(\mathrm{~d},{ }^{3} J_{\mathrm{H}, \mathrm{H}}=4.8 \mathrm{~Hz}, 1 \mathrm{H}, \mathrm{H}^{6}\right), 7.72-7.75\left(\mathrm{~m}, 2 \mathrm{H}, \mathrm{H}^{3}+\mathrm{H}^{4}\right)$, $7.66\left(\mathrm{~s}, 2 \mathrm{H}, \mathrm{H}^{2}\right), 7.21\left(\mathrm{ddd},{ }^{3} J_{\mathrm{H}, \mathrm{H}}=6.1 \mathrm{~Hz},{ }^{3} J_{\mathrm{H}, \mathrm{H}}=4.8 \mathrm{~Hz},{ }^{4} J_{\mathrm{H}, \mathrm{H}}\right.$ $\left.=2.5 \mathrm{~Hz}, 1 \mathrm{H}, \mathrm{H}^{5}\right), 7.15\left(\mathrm{~s}, 1 \mathrm{H}, \mathrm{H}^{4^{\prime}}\right), 2.99\left(\mathrm{sp},{ }^{3} J_{\mathrm{H}, \mathrm{H}}=7.0 \mathrm{~Hz}, 2 \mathrm{H}\right.$, $\left.\mathrm{CH}\left(\mathrm{CH}_{3}\right)_{2}\right), 1.31 \mathrm{ppm}\left(\mathrm{d},{ }^{3} J_{\mathrm{H}, \mathrm{H}}=7.0 \mathrm{~Hz}, 12 \mathrm{H}, \mathrm{CH}\left(\mathrm{CH}_{3}\right)_{2}\right) .{ }^{13} \mathrm{C}$ NMR (151 MHz, $\left.\mathrm{CDCl}_{3}\right)$ : $\delta 158.2\left(\mathrm{C}^{2}\right), 149.6\left(\mathrm{C}^{6}\right), 149.3\left(\mathrm{C}^{3^{\prime}}\right)$, 139.4 $\left(\mathrm{C}^{1^{\prime}}\right), 136.6\left(\mathrm{C}^{4}\right), 125.4\left(\mathrm{C}^{4^{\prime}}\right), 122.7\left(\mathrm{C}^{2^{\prime}}\right), 121.8\left(\mathrm{C}^{5}\right), 120.8$ $\left(\mathrm{C}^{3}\right), 34.3\left(\mathrm{CH}\left(\mathrm{CH}_{3}\right)_{2}\right), 24.1 \mathrm{ppm}\left(\mathrm{CH}\left(\mathrm{CH}_{3}\right)_{2}\right) .{ }^{15} \mathrm{~N}\left\{{ }^{1} \mathrm{H}\right\}$ NMR (600 $\mathrm{MHz}, \mathrm{CD}_{2} \mathrm{Cl}_{2}$ ): $\delta-73.6 \mathrm{ppm}\left(\mathrm{N}^{1}\right)$. MS (ESI): $\mathrm{m} / z$ (rel. \%): 240.175 (100) $[\mathrm{M}+\mathrm{H}]^{+}$. HRMS (ESI): Found 240.1746. Calc. for $\mathrm{C}_{17} \mathrm{H}_{22} \mathrm{~N}[\mathrm{M}+\mathrm{H}]^{+}:$240.1747. Elemental analysis: Found: C, 85.3; H, 8.9; N, 5.85. Calc. for $\mathrm{C}_{17} \mathrm{H}_{21} \mathrm{~N}$ : C, 85.3; H, 8.8; N, $5.85 \%$.

2-(3,5-Diethylphenyl)pyridine (1t). The general procedure was followed. 2-Bromopyridine $(0.670 \mathrm{~g}, 4.26 \mathrm{mmol}, 1.0$ equiv.), 3,5-diethylphenylboronic acid (0.670 g, $4.26 \mathrm{mmol}, 1.0$ equiv.), $\mathrm{K}_{3} \mathrm{PO}_{4}$ (1.81 g, $8.52 \mathrm{mmol}, 2.0$ equiv.), $\mathrm{Pd}(\mathrm{OAc})_{2}$ (0.0187 g, $0.0831 \mathrm{mmol}, 2.0 \mathrm{~mol} \%)$ and $\mathrm{PPh}_{3}(0.0664 \mathrm{~g}$, $0.253 \mathrm{mmol}, 6.0 \mathrm{~mol} \%$ ) were used. The crude product was purified by flash column chromatography (85\% hexanes/15\% EtOAc), yielding 1t as a colourless oil (0.438 g, $2.070 \mathrm{mmol}$, $49 \%$ ). ${ }^{1} \mathrm{H}$ NMR (600 MHz, $\mathrm{CDCl}_{3}$ ): $\delta 8.69-8.71$ (ddd, ${ }^{3} J_{\mathrm{H}, \mathrm{H}}=4.7$ $\left.\mathrm{Hz},{ }^{4} J_{\mathrm{H}, \mathrm{H}}=1.3 \mathrm{~Hz},{ }^{5} J_{\mathrm{H}, \mathrm{H}}=1.3 \mathrm{~Hz}, 1 \mathrm{H}, \mathrm{H}^{6}\right), 7.72-7.74(\mathrm{~m}, 2 \mathrm{H}$, $\left.\mathrm{H}^{3}+\mathrm{H}^{4}\right), 7.65\left(\mathrm{~d},{ }^{4} J_{\mathrm{H}, \mathrm{H}}=1.2 \mathrm{~Hz}, 2 \mathrm{H}, \mathrm{H}^{2^{\prime}}\right), 7.20-7.22(\mathrm{~m}, 1 \mathrm{H}$, $\mathrm{H}^{5}$ ), $7.11\left(\mathrm{~s}, 1 \mathrm{H}, \mathrm{H}^{4^{\prime}}\right), 2.73\left(\mathrm{q},{ }^{3} J_{\mathrm{H}, \mathrm{H}}=7.6 \mathrm{~Hz}, 4 \mathrm{H}, \mathrm{CH}_{2} \mathrm{CH}_{3}\right.$ ), $1.30 \mathrm{ppm}\left(\mathrm{t},{ }^{3} \mathrm{~J}_{\mathrm{H}, \mathrm{H}}=7.6 \mathrm{~Hz}, 6 \mathrm{H}, \mathrm{CH}_{2} \mathrm{CH}_{3}\right) .{ }^{13} \mathrm{C} \mathrm{NMR}(151 \mathrm{MHz}$, $\left.\mathrm{CDCl}_{3}\right): \delta 158.0\left(\mathrm{C}^{2}\right), 149.5\left(\mathrm{C}^{6}\right), 144.7\left(\mathrm{C}^{3^{\prime}}\right), 139.4\left(\mathrm{C}^{1^{\prime}}\right), 136.6$ $\left(\mathrm{C}^{4}\right), 128.3\left(\mathrm{C}^{4^{\prime}}\right), 123.9\left(\mathrm{C}^{2}\right), 121.8\left(\mathrm{C}^{5}\right), 120.7\left(\mathrm{C}^{3}\right), 28.6$ $\left(\mathrm{CH}_{2} \mathrm{CH}_{3}\right), 15.6 \mathrm{ppm}\left(\mathrm{CH}_{2} \mathrm{CH}_{3}\right) .{ }^{15} \mathrm{~N}\left\{{ }^{1} \mathrm{H}\right\} \mathrm{NMR}(600 \mathrm{MHz}$, $\mathrm{CD}_{2} \mathrm{Cl}_{2}$ ): $\delta-73.6 \mathrm{ppm}\left(\mathrm{N}^{1}\right)$. MS (ESI): $\mathrm{m} / z$ (rel. \%): 212.143 (100) $[\mathrm{M}+\mathrm{H}]^{+}$. HRMS (ESI): Found 212.1433. Calc. for $\mathrm{C}_{15} \mathrm{H}_{18} \mathrm{~N}[\mathrm{M}+$ $\mathrm{H}^{+}$: 212.1434. Elemental analysis: Found: C, 85.2; H, 8.1; N, 6.6. Calc. for $\mathrm{C}_{15} \mathrm{H}_{17} \mathrm{~N}$ : C, 85.3; H, 8.1; N, 6.6\%.

$2 \mathbf{c}-\mathbf{A u}\left(\mathbf{O A c}^{\mathbf{F}}\right)_{2}$. A microwave vessel was charged with $\mathrm{Au}(\mathrm{OAc})_{3}$ (0.373 g, $0.999 \mathrm{mmol}, 1.00$ equiv.) and 1c (0.193 g, $1.01 \mathrm{mmol}$, 1.01 equiv.) in a $1: 1$ mixture of $\operatorname{HOAc}^{\mathrm{F}}$ and water $(30 \mathrm{~mL})$. The reaction mixture was heated at $120{ }^{\circ} \mathrm{C}$ for $30 \mathrm{~min}$ in a microwave. After cooling to room temperature, $\operatorname{HOAc}^{\mathrm{F}}(30 \mathrm{~mL})$ was added to dissolve partially precipitated product, and the resulting solution was filtered. Water $(50 \mathrm{~mL})$ was added to the filtrate, resulting in the precipitation of a solid. After cooling on an ice-water bath for $15 \mathrm{~min}$, the precipitate was filtered off, washed with water $(3 \times 5 \mathrm{~mL})$ and $\mathrm{Et}_{2} \mathrm{O}(5 \mathrm{~mL})$, and dried under a stream of air for ca. $3 \mathrm{~h}$, furnishing $\mathbf{2 c - A u (}(\mathbf{O A c})_{2}$ as a colourless solid $(0.527 \mathrm{~g}, 0.860 \mathrm{mmol}, 85 \%) .{ }^{1} \mathrm{H} \quad \mathrm{NMR}$ $\left(800 \mathrm{MHz}, \mathrm{CD}_{2} \mathrm{Cl}_{2}\right): \delta 8.62\left(\mathrm{dd},{ }^{3} J_{\mathrm{H}, \mathrm{H}}=6.0 \mathrm{~Hz},{ }^{4} J_{\mathrm{H}, \mathrm{H}}=1.0 \mathrm{~Hz}\right.$, $\left.\mathrm{H}^{6}\right), 8.33\left(\mathrm{ddd},{ }^{3} J_{\mathrm{H}, \mathrm{H}}=7.9 \mathrm{~Hz},{ }^{3} J_{\mathrm{H}, \mathrm{H}}=7.8 \mathrm{~Hz},{ }^{4} J_{\mathrm{H}, \mathrm{H}}=1.4 \mathrm{~Hz}\right.$, $\left.\mathrm{H}^{4}\right), 7.95\left(\mathrm{~d},{ }^{3} J_{\mathrm{H}, \mathrm{H}}=8.1 \mathrm{~Hz}, \mathrm{H}^{3}\right), 7.66\left(\mathrm{ddd},{ }^{3} J_{\mathrm{H}, \mathrm{H}}=7.6 \mathrm{~Hz},{ }^{3} J_{\mathrm{H}, \mathrm{H}}\right.$ $\left.=6.0 \mathrm{~Hz},{ }^{4} J_{\mathrm{H}, \mathrm{H}}=1.3 \mathrm{~Hz}, \mathrm{H}^{5}\right), 7.28\left(\mathrm{dd},{ }^{3} J_{\mathrm{H}, \mathrm{F}}=7.8 \mathrm{~Hz},{ }^{4} J_{\mathrm{H}, \mathrm{H}}=2.4\right.$ $\left.\mathrm{Hz}, \mathrm{H}^{6^{\prime}}\right), 6.87 \mathrm{ppm}\left(\mathrm{ddd},{ }^{3} J_{\mathrm{H}, \mathrm{F}}=9.1 \mathrm{~Hz},{ }^{3} J_{\mathrm{H}, \mathrm{F}}=9.1 \mathrm{~Hz},{ }^{4} J_{\mathrm{H}, \mathrm{H}}=\right.$ $\left.2.5 \mathrm{~Hz}, \mathrm{H}^{4^{\prime}}\right) .{ }^{13} \mathrm{C}$ NMR (201 MHz, $\left.\mathrm{CD}_{2} \mathrm{Cl}_{2}\right): \delta 164.1\left(\mathrm{C}^{2}\right), 164.0$ $\left(\mathrm{dd},{ }^{1} J_{\mathrm{C}, \mathrm{F}}=251.5 \mathrm{~Hz},{ }^{3} J_{\mathrm{C}, \mathrm{F}}=12.0 \mathrm{~Hz}, \mathrm{C}^{3^{\prime}}\right.$ or $\left.\mathrm{C}^{5^{\prime}}\right), 162.8\left(\mathrm{dd},{ }^{1} J_{\mathrm{C}, \mathrm{F}}\right.$ $=253.4 \mathrm{~Hz},{ }^{3} J_{\mathrm{C}, \mathrm{F}}=12.1 \mathrm{~Hz}, \mathrm{C}^{3^{\prime}}$ or $\left.\mathrm{C}^{5^{\prime}}\right), 161.1\left(\mathrm{q},{ }^{2} J_{\mathrm{C}, \mathrm{F}}=38.2 \mathrm{~Hz}\right.$, $\left.\mathrm{OCOCF}_{3}\right), 161.0\left(\mathrm{q},{ }^{2} J_{\mathrm{C}, \mathrm{F}}=39.5 \mathrm{~Hz}, \mathrm{OCOCF}_{3}\right), 148.2\left(\mathrm{C}^{6}\right), 145.4$ $\left(\mathrm{C}^{4}\right), 145.1\left(\mathrm{dd},{ }^{3} J_{\mathrm{C}, \mathrm{F}}=9.9 \mathrm{~Hz},{ }^{3} J_{\mathrm{C}, \mathrm{F}}=9.6 \mathrm{~Hz}, \mathrm{C}^{1}\right), 126.4\left(\mathrm{C}^{5}\right)$, $122.9\left(\mathrm{C}^{3}\right), 118.8\left(\mathrm{dd},{ }^{2} J_{\mathrm{C}, \mathrm{F}}=25.3 \mathrm{~Hz},{ }^{4} J_{\mathrm{C}, \mathrm{F}}=3.6 \mathrm{~Hz}, \mathrm{C}^{2}\right), 118.0$ $\left(\mathrm{q},{ }^{1} J_{\mathrm{C}, \mathrm{F}}=288.6 \mathrm{~Hz}, \mathrm{OCOCF}_{3}\right), 115.5\left(\mathrm{q},{ }^{1} J_{\mathrm{C}, \mathrm{F}}=287.8 \mathrm{~Hz}\right.$, $\left.\mathrm{OCOCF}_{3}\right), 109.2-109.5 \mathrm{ppm}\left(\mathrm{m}, \mathrm{C}^{4^{\prime}}+\mathrm{C}^{6^{\prime}}\right) .{ }^{19} \mathrm{~F}$ NMR $(188 \mathrm{MHz}$, $\left.\mathrm{CD}_{2} \mathrm{Cl}_{2}\right): \delta-75.5\left(\mathrm{~d},{ }^{7} J_{\mathrm{F}, \mathrm{F}}=4.0 \mathrm{~Hz}, 3 \mathrm{~F}, \mathrm{OCOCF}_{3}(\right.$ trans $\left.-\mathrm{N})\right),-77.0$ $\left(\mathrm{s}, 3 \mathrm{~F}, \mathrm{OCOCF}_{3}\left(\right.\right.$ cis-N)), -102.46 to $-102.53\left(\mathrm{~m}, 1 \mathrm{~F}, \mathrm{ArF}^{1}\right)$, -109.2 ppm (d, ${ }^{4} J_{\mathrm{F}, \mathrm{F}}=10.0 \mathrm{~Hz}, 1 \mathrm{~F}, \mathrm{ArF}^{2}$ ). MS (ESI): $m / z$ (rel. \%): 499.998 (90) $\left[\mathrm{M}-\mathrm{OCOCF}_{3}\right]^{+}$. HRMS (ESI): Found: 499.9979. Calc. for $\mathrm{C}_{13} \mathrm{H}_{6} \mathrm{AuF}_{5} \mathrm{NO}_{2}\left[\mathrm{M}-\mathrm{OCOCF}_{3}\right]^{+}$: 499.9979. Elemental analysis: Found: $\mathrm{C}, 29.4 ; \mathrm{H}, 1.0 ; \mathrm{N}, 2.3$. Calc. for $\mathrm{C}_{15} \mathrm{H}_{6} \mathrm{AuF}_{8} \mathrm{NO}_{4}$ : C, 29.4; H, 1.0; N, 2.3\%.

$\mathbf{2 m - A u}\left(\mathbf{O A c}^{\mathbf{F}}\right)_{2}$. A microwave vessel was charged with $\mathrm{Au}$ $(\mathrm{OAc})_{3}(0.0750 \mathrm{~g}, 0.200 \mathrm{mmol}, 1.00 \mathrm{equiv}$.$) and 1 \mathrm{~m}(0.0400 \mathrm{~g}$, $0.202 \mathrm{mmol}, 1.01$ equiv.) in a $1: 1$ mixture of $\mathrm{HOAc}^{\mathrm{F}}$ and water $(6 \mathrm{~mL})$. The reaction mixture was heated at $100{ }^{\circ} \mathrm{C}$ for $60 \mathrm{~min}$ in a microwave. After cooling to room temperature, $\mathrm{HOAc}^{\mathrm{F}}$ (1 $\mathrm{mL}$ ) was added, and the resulting solution was filtered. Water $(8 \mathrm{~mL})$ was added to the filtrate, resulting in the precipi- 
tation of a solid. After cooling on an ice-water bath for $10 \mathrm{~min}$, the precipitate was filtered off, washed with water $(3 \times 5 \mathrm{~mL})$ and $\mathrm{Et}_{2} \mathrm{O}(5 \mathrm{~mL})$, and dried under a stream of air for $c a .3 \mathrm{~h}$, furnishing $\mathbf{2 m - A u}\left(\mathbf{O A c} \mathbf{c}^{\mathbf{F}}\right)_{2}$ as a pale yellow solid $(0.0660 \mathrm{~g}$, $0.106 \mathrm{mmol}, 53 \%) .{ }^{1} \mathrm{H}$ NMR (800 $\mathrm{MHz}, \mathrm{CD}_{2} \mathrm{Cl}_{2}$ ): $\delta 8.09$ (dd, $\left.{ }^{3} J_{\mathrm{H}, \mathrm{H}}=8.2 \mathrm{~Hz},{ }^{3} J_{\mathrm{H}, \mathrm{H}}=7.8 \mathrm{~Hz}, 1 \mathrm{H}, \mathrm{H}^{4}\right), 7.42\left(\mathrm{dd},{ }^{3} J_{\mathrm{H}, \mathrm{H}}=7.7 \mathrm{~Hz}\right.$, $\left.{ }^{4} J_{\mathrm{H}, \mathrm{H}}=0.9 \mathrm{~Hz}, 1 \mathrm{H}, \mathrm{H}^{3}\right), 7.35\left(\mathrm{~d},{ }^{3} J_{\mathrm{H}, \mathrm{H}}=7.9 \mathrm{~Hz}, 1 \mathrm{H}, \mathrm{H}^{6^{\prime}}\right)$, 7.23-7.25 (m, 1H, $\left.\mathrm{H}^{5^{\prime}}\right), 6.82\left(\mathrm{~d},{ }^{4} J_{\mathrm{H}, \mathrm{H}}=0.6 \mathrm{~Hz}, 1 \mathrm{H}, \mathrm{H}^{3^{\prime}}\right), 6.81$ $\left(\mathrm{dd},{ }^{3} J_{\mathrm{H}, \mathrm{H}}=8.5 \mathrm{~Hz},{ }^{4} J_{\mathrm{H}, \mathrm{H}}=0.8 \mathrm{~Hz}, 1 \mathrm{H}, \mathrm{H}^{5}\right), 4.01\left(\mathrm{~s}, 3 \mathrm{H}, \mathrm{OCH}_{3}\right)$, $2.40 \mathrm{ppm}\left(\mathrm{s}, 3 \mathrm{H}, \mathrm{Ar}-\mathrm{CH}_{3}\right) .{ }^{13} \mathrm{C} \mathrm{NMR}\left(201 \mathrm{MHz}, \mathrm{CD}_{2} \mathrm{Cl}_{2}\right): \delta 165.1$ $\left(\mathrm{C}^{6}\right), 163.7\left(\mathrm{C}^{2}\right), 161.1\left(\mathrm{q},{ }^{2} J_{\mathrm{C}, \mathrm{F}}=36.6 \mathrm{~Hz}, \mathrm{OCOCF}_{3}\right), 160.4$ (q, $\left.{ }^{2} J_{\mathrm{C}, \mathrm{F}}=39.6 \mathrm{~Hz}, \mathrm{OCOCF}_{3}\right), 146.6\left(\mathrm{C}^{4}\right), 143.8\left(\mathrm{C}^{4^{\prime}}\right), 141.7\left(\mathrm{C}^{2^{\prime}}\right)$, $139.5\left(\mathrm{C}^{1^{\prime}}\right), 131.3\left(\mathrm{C}^{5^{\prime}}\right), 128.7\left(\mathrm{C}^{3^{\prime}}\right), 125.9\left(\mathrm{C}^{6^{\prime}}\right), 118.7\left(\mathrm{q},{ }^{1} J_{\mathrm{C}, \mathrm{F}}=\right.$ $\left.289.6 \mathrm{~Hz}, \mathrm{OCOCF}_{3}\right), 116.1$ (q, $\left.{ }^{1} J_{\mathrm{C}, \mathrm{F}}=288.1 \mathrm{~Hz}, \mathrm{OCOCF}_{3}\right), 113.3$ $\left(\mathrm{C}^{3}\right), 106.9\left(\mathrm{C}^{5}\right), 58.0\left(\mathrm{OCH}_{3}\right), 22.3 \mathrm{ppm}\left(\mathrm{Ar}-\mathrm{CH}_{3}\right) .{ }^{19} \mathrm{~F} \mathrm{NMR}$ $\left(376 \mathrm{MHz}, \mathrm{CD}_{2} \mathrm{Cl}_{2}\right): \delta-76.2\left(\mathrm{~s}, 3 \mathrm{~F}, \mathrm{OCOCF}_{3}\right),-76.5 \mathrm{ppm}$ (broadened s, 3F, OCOCF 3 ). ${ }^{15} \mathrm{~N}\left\{{ }^{1} \mathrm{H}\right\} \mathrm{NMR}\left(600 \mathrm{MHz}, \mathrm{CD}_{2} \mathrm{Cl}_{2}\right.$ ): $\delta-187.7$ ppm $\left(\mathrm{N}^{1}\right)$. MS (ESI): $\mathrm{m} / z$ (rel. \%): 426.076 (100) [M $2 \mathrm{OCOCF}_{3}+\mathrm{OMe}^{+}$. HRMS (ESI): Found: 426.0761. Calc. for $\mathrm{C}_{14} \mathrm{H}_{15} \mathrm{AuNO}_{2}\left[\mathrm{M}-2 \mathrm{OCOCF}_{3}+\mathrm{OMe}^{+}:\right.$426.0763. Elemental analysis: Found: $\mathrm{C}, 32.8 ; \mathrm{H}, 2.0 ; \mathrm{N}, 2.3$. Calc. for $\mathrm{C}_{17} \mathrm{H}_{12} \mathrm{AuF}_{6} \mathrm{NO}_{5}$ : C, 32.9; H, 1.95; N, 2.25\%.

$2 \mathbf{r}-\mathbf{A u}\left(\mathbf{O A c}^{\mathbf{F}}\right)_{2}$. A microwave vessel was charged with $\mathrm{Au}(\mathrm{OAc})_{3}$ $(0.0750 \mathrm{~g}, 0.200 \mathrm{mmol}, 1.00$ equiv. $)$ and $1 \mathrm{r}(0.0980 \mathrm{~g}$, 0.202 mmol, 1.01 equiv.) in a $1: 1$ mixture of $\mathrm{HOAc}^{\mathrm{F}}$ and water $(6 \mathrm{~mL})$. The reaction mixture was heated at $120^{\circ} \mathrm{C}$ for $60 \mathrm{~min}$ in a microwave. After cooling to room temperature, $\mathrm{HOAc}^{\mathrm{F}}$ (2 $\mathrm{mL}$ ) was added, and the resulting solution was filtered. Water $(20 \mathrm{~mL})$ was added to the filtrate, resulting in the precipitation of a solid. After cooling on an ice-water bath for $15 \mathrm{~min}$, and then overnight at $4-8{ }^{\circ} \mathrm{C}$, the precipitate was filtered off, washed with water $(3 \times 5 \mathrm{~mL})$ and $\mathrm{Et}_{2} \mathrm{O}(5 \mathrm{~mL})$, and dried under a stream of air for ca. $3 \mathrm{~h}$, furnishing $\mathbf{2 r}-\mathbf{A u}\left(\mathbf{O A c} \mathbf{F}^{\mathbf{F}}\right)_{2}$ as a colourless solid (0.0740 g, $0.0810 \mathrm{mmol}, 41 \%) .{ }^{1} \mathrm{H}$ NMR $\left(800 \mathrm{MHz}, \mathrm{CD}_{2} \mathrm{Cl}_{2}\right): \delta 8.61\left(\mathrm{dd},{ }^{3} J_{\mathrm{H}, \mathrm{H}}=6.1 \mathrm{~Hz},{ }^{4} J_{\mathrm{H}, \mathrm{H}}=1.0 \mathrm{~Hz}\right.$, $\left.1 \mathrm{H}, \mathrm{H}^{6}\right), 8.34\left(\mathrm{ddd},{ }^{3} J_{\mathrm{H}, \mathrm{H}}=8.1 \mathrm{~Hz},{ }^{3} J_{\mathrm{H}, \mathrm{H}}=7.7 \mathrm{~Hz},{ }^{4} J_{\mathrm{H}, \mathrm{H}}=1.4\right.$ $\left.\mathrm{Hz}, 1 \mathrm{H}, \mathrm{H}^{4}\right), 8.05\left(\mathrm{dd},{ }^{3} J_{\mathrm{H}, \mathrm{H}}=8.2 \mathrm{~Hz},{ }^{4} J_{\mathrm{H}, \mathrm{H}}=1.2 \mathrm{~Hz}, 1 \mathrm{H}, \mathrm{H}^{3}\right)$, $7.80\left(\mathrm{~s}, 1 \mathrm{H}, \mathrm{H}^{6}\right), 7.65\left(\mathrm{ddd},{ }^{3} J_{\mathrm{H}, \mathrm{H}}=7.6 \mathrm{~Hz},{ }^{3} J_{\mathrm{H}, \mathrm{H}}=6.1 \mathrm{~Hz},{ }^{4} J_{\mathrm{H}, \mathrm{H}}\right.$ $\left.=1.4 \mathrm{~Hz}, 1 \mathrm{H}, \mathrm{H}^{5}\right), 7.27 \mathrm{ppm}\left(\mathrm{s}, 1 \mathrm{H}, \mathrm{H}^{4^{\prime}}\right) .{ }^{13} \mathrm{C} \mathrm{NMR}(201 \mathrm{MHz}$, $\left.\mathrm{CD}_{2} \mathrm{Cl}_{2}\right): \delta 164.3\left(\mathrm{C}^{2}\right), 161.2\left(\mathrm{q},{ }^{2} J_{\mathrm{C}, \mathrm{F}}=38.4 \mathrm{~Hz}, \mathrm{OCOCF}_{3}\right), 160.4$ $\left(\mathrm{q},{ }^{2} J_{\mathrm{C}, \mathrm{F}}=39.6 \mathrm{~Hz}, \mathrm{OCOCF}_{3}\right), 148.4\left(\mathrm{C}^{6}\right), 145.4\left(\mathrm{C}^{4}\right), 144.6(\mathrm{~m}$, $2 \times \mathrm{Ar}-C-\mathrm{F}), 142.2\left(\mathrm{~d},{ }^{1} J_{\mathrm{C}, \mathrm{F}}=254.8 \mathrm{~Hz}, \mathrm{Ar}-C-\mathrm{F}\right), 141.9\left(\mathrm{~d},{ }^{1} J_{\mathrm{C}, \mathrm{F}}=\right.$ $256.2 \mathrm{~Hz}, \mathrm{Ar}-\mathrm{C}-\mathrm{F}), 141.1\left(\mathrm{C}^{3^{\prime}}+\mathrm{C}^{5^{\prime}}\right), 138.6\left(\mathrm{~d},{ }^{1} J_{\mathrm{C}, \mathrm{F}}=252.5 \mathrm{~Hz}\right.$, $\mathrm{Ar}-C-\mathrm{F}), 137.6\left(\mathrm{C}^{4^{\prime}}\right), 137.2\left(\mathrm{~d},{ }^{1} J_{\mathrm{C}, \mathrm{F}}=251.1 \mathrm{~Hz}, \mathrm{Ar}-C-\mathrm{F}\right), 130.8$ $\left(\mathrm{C}^{1^{\prime}}\right.$ or $\left.\mathrm{C}^{2^{\prime}}\right), 129.4\left(\mathrm{C}^{1^{\prime}}\right.$ or $\left.\mathrm{C}^{2^{\prime}}\right), 128.3\left(\mathrm{C}^{6^{\prime}}\right), 126.3\left(\mathrm{C}^{5}\right), 122.8\left(\mathrm{C}^{3}\right)$, $117.9\left(\mathrm{q},{ }^{1} J_{\mathrm{C}, \mathrm{F}}=288.4 \mathrm{~Hz}, \mathrm{OCOCF}_{3}\right), 115.1\left(\mathrm{q},{ }^{1} J_{\mathrm{C}, \mathrm{F}}=288.1 \mathrm{~Hz}\right.$, $\left.\mathrm{OCOCF}_{3}\right), 113.0 \mathrm{ppm}(\mathrm{m}, 2 \times \mathrm{Ar}-\mathrm{C}-\mathrm{C}-\mathrm{F}) .{ }^{19} \mathrm{~F} \mathrm{NMR}(470 \mathrm{MHz}$, $\left.\mathrm{CD}_{2} \mathrm{Cl}_{2}\right): \delta-75.6\left(\mathrm{~s}, 3 \mathrm{~F}, \mathrm{OCOCF}_{3}\right),-77.1\left(\mathrm{~s}, 3 \mathrm{~F}, \mathrm{OCOCF}_{3}\right)$, $-143.8\left(\mathrm{dd},{ }^{3} J_{\mathrm{F}, \mathrm{F}}=22.1 \mathrm{~Hz},{ }^{4} J_{\mathrm{F}, \mathrm{F}}=7.5 \mathrm{~Hz}, 2 \mathrm{~F}, \mathrm{C}_{6} \mathrm{~F}_{5}\right),-145.2(\mathrm{dd}$, $\left.{ }^{3} J_{\mathrm{F}, \mathrm{F}}=23.1 \mathrm{~Hz},{ }^{4} J_{\mathrm{F}, \mathrm{F}}=7.5 \mathrm{~Hz}, 2 \mathrm{~F}, \mathrm{C}_{6} \mathrm{~F}_{5}\right),-155.0\left(\mathrm{dd},{ }^{3} J_{\mathrm{F}, \mathrm{F}}=21.3\right.$ $\left.\mathrm{Hz},{ }^{3} J_{\mathrm{F}, \mathrm{F}}=20.3 \mathrm{~Hz}, 1 \mathrm{~F}, \mathrm{C}_{6} \mathrm{~F}_{5}\right),-156.3\left(\mathrm{dd},{ }^{3} J_{\mathrm{F}, \mathrm{F}}=20.8 \mathrm{~Hz},{ }^{3} J_{\mathrm{F}, \mathrm{F}}=\right.$ $\left.20.2 \mathrm{~Hz}, 1 \mathrm{~F}, \mathrm{C}_{6} \mathrm{~F}_{5}\right),-163.6\left(\mathrm{~m}, 2 \mathrm{~F}, \mathrm{C}_{6} \mathrm{~F}_{5}\right),-164.7 \mathrm{ppm}(\mathrm{m}, 2 \mathrm{~F}$, $\left.\mathrm{C}_{6} \mathrm{~F}_{5}\right) .{ }^{15} \mathrm{~N}\left\{{ }^{1} \mathrm{H}\right\}$ NMR (800 MHz, $\left.\mathrm{CD}_{2} \mathrm{Cl}_{2}\right): \delta-167.7 \mathrm{ppm}\left(\mathrm{N}^{1}\right)$. MS (ESI): $m / z$ (rel. \%): 714.019 (15) $\left[\mathrm{M}-2 \mathrm{OCOCF}_{3}+\mathrm{OMe}^{+}\right.$, $768.027(70)\left[\mathrm{M}-2 \mathrm{OCOCF}_{3}+2 \mathrm{OMe}+\mathrm{Na}\right]^{+}, 800.053$ (100) $[\mathrm{M}-$ $\left.2 \mathrm{OCOCF}_{3}+2 \mathrm{OMe}+\mathrm{MeOH}+\mathrm{Na}\right]^{+}$. HRMS (ESI): Found:
768.0269. Calc. for $\mathrm{C}_{25} \mathrm{H}_{12} \mathrm{AuF}_{10} \mathrm{NNaO}_{2}\left[\mathrm{M}-2 \mathrm{OCOCF}_{3}+2 \mathrm{OMe}\right.$ $+\mathrm{Na}]^{+}:$768.0266. Elemental analysis: Found: C, 35.6; H, 0.7; N, 1.5. Calc. for $\mathrm{C}_{26} \mathrm{H}_{6} \mathrm{AuF}_{16} \mathrm{NO}_{4}$ : C, 35.7; $\mathrm{H}, 0.7 ; \mathrm{N}, 1.5 \%$.

3s-AuOAc ${ }^{\mathbf{F}}$. A microwave vessel was charged with $\mathrm{Au}(\mathrm{OAc})_{3}$ (0.0750 g, $0.200 \mathrm{mmol}, 1.00$ equiv.) and $1 \mathrm{~s}(0.0480 \mathrm{~g}$, $0.202 \mathrm{mmol}, 1.01$ equiv.) in a 1:1 mixture of $\operatorname{HOAc}^{\mathrm{F}}$ and water $(6 \mathrm{~mL})$. The reaction mixture was heated at $80{ }^{\circ} \mathrm{C}$ for $3.5 \mathrm{~h}$ in a microwave. The reaction mixture was kept at $4-8{ }^{\circ} \mathrm{C}$ overnight. Addition of $\operatorname{HOAc}^{\mathrm{F}}(4 \mathrm{~mL})$, followed by water $(6 \mathrm{~mL})$, furnishing a white precipitate. The precipitate was collected by filtration, and washed with water $(3 \times 3 \mathrm{~mL})$. The title compound was obtained as a colourless solid $(0.0410 \mathrm{~g}, 0.0750 \mathrm{mmol}$, $38 \%) .{ }^{1} \mathrm{H}$ NMR (600 MHz, $\left.\mathrm{CD}_{2} \mathrm{Cl}_{2}\right): \delta 8.48\left(\mathrm{ddd},{ }^{3} J_{\mathrm{H}, \mathrm{H}}=5.4 \mathrm{~Hz}\right.$, $\left.{ }^{4} J_{\mathrm{H}, \mathrm{H}}=1.4 \mathrm{~Hz},{ }^{5} J_{\mathrm{H}, \mathrm{H}}=0.8 \mathrm{~Hz}, 1 \mathrm{H}, \mathrm{H}^{6}\right), 7.99-8.03\left(\mathrm{~m}, 1 \mathrm{H}, \mathrm{H}^{4}\right)$, $7.94\left(\mathrm{~d},{ }^{3} J_{\mathrm{H}, \mathrm{H}}=8.1 \mathrm{~Hz}, 1 \mathrm{H}, \mathrm{H}^{3}\right), 7.50\left(\mathrm{ddd},{ }^{3} J_{\mathrm{H}, \mathrm{H}}=7.5 \mathrm{~Hz},{ }^{3} J_{\mathrm{H}, \mathrm{H}}\right.$ $\left.=5.4 \mathrm{~Hz},{ }^{4} J_{\mathrm{H}, \mathrm{H}}=1.3 \mathrm{~Hz}, 1 \mathrm{H}, \mathrm{H}^{5}\right), 7.35\left(\mathrm{~s}, 1 \mathrm{H}, \mathrm{H}^{6^{\prime}}\right), 6.92(\mathrm{~s}, 1 \mathrm{H}$, $\left.\mathrm{H}^{4}\right), 3.50\left(\mathrm{sx},{ }^{3} \mathrm{~J}_{\mathrm{H}, \mathrm{H}}=6.8 \mathrm{~Hz}, 1 \mathrm{H}, \mathrm{Ar}-\mathrm{CH}\left(\mathrm{CH}_{2} \mathrm{Au}\right) \mathrm{CH}_{3}\right), 3.38$ (dd, $\left.{ }^{2} J_{\mathrm{H}, \mathrm{H}}=10.4 \mathrm{~Hz},{ }^{3} J_{\mathrm{H}, \mathrm{H}}=7.3 \mathrm{~Hz}, 1 \mathrm{H}, \mathrm{Ar}-\mathrm{CH}\left(\mathrm{CH}_{2} \mathrm{Au}\right) \mathrm{CH}_{3}\right), 2.97$ $\left(\mathrm{dd},{ }^{2} J_{\mathrm{H}, \mathrm{H}}=10.4 \mathrm{~Hz},{ }^{3} J_{\mathrm{H}, \mathrm{H}}=5.6 \mathrm{~Hz}, 1 \mathrm{H}, \mathrm{Ar}-\mathrm{CH}\left(\mathrm{CH}_{2} \mathrm{Au}\right) \mathrm{CH}_{3}\right)$, $2.94\left(\mathrm{sp},{ }^{3} J_{\mathrm{H}, \mathrm{H}}=6.9 \mathrm{~Hz}, 1 \mathrm{H}, \mathrm{Ar}-\mathrm{CH}\left(\mathrm{CH}_{3}\right)_{2}\right), 1.35\left(\mathrm{~d},{ }^{3} J_{\mathrm{H}, \mathrm{H}}=7.0\right.$ $\left.\mathrm{Hz}, 3 \mathrm{H}, \mathrm{Ar}-\mathrm{CH}\left(\mathrm{CH}_{2} \mathrm{Au}\right) \mathrm{CH}_{3}\right), 1.290\left(\mathrm{~d},{ }^{3} J_{\mathrm{H}, \mathrm{H}}=6.9 \mathrm{~Hz}, 3 \mathrm{H}, \mathrm{Ar}-\right.$ $\left.\mathrm{CH}\left(\mathrm{CH}_{3}\right)_{2}\right), 1.287 \mathrm{ppm}\left(\mathrm{d},{ }^{3} J_{\mathrm{H}, \mathrm{H}}=6.9 \mathrm{~Hz}, 3 \mathrm{H}, \mathrm{Ar}-\mathrm{CH}\left(\mathrm{CH}_{3}\right)_{2}\right)$. ${ }^{13} \mathrm{C}$ NMR (151 MHz, $\mathrm{CD}_{2} \mathrm{Cl}_{2}$ ): $\delta 162.2\left(\mathrm{C}^{2}\right), 161.5\left(\mathrm{q},{ }^{2} J_{\mathrm{C}, \mathrm{F}}=36.5\right.$ $\left.\mathrm{Hz}, \mathrm{OCOCF}_{3}\right), 161.2\left(\mathrm{C}^{3^{\prime}}\right), 149.8\left(\mathrm{C}^{5^{\prime}}\right), 148.1\left(\mathrm{C}^{6}\right), 146.3\left(\mathrm{C}^{1^{\prime}}\right)$, $141.5\left(C^{4}\right), 139.7\left(C^{2}\right), 126.1\left(C^{4^{\prime}}\right), 125.1\left(C^{5}\right), 121.1\left(C^{6^{\prime}}\right), 120.8$ $\left(\mathrm{C}^{3}\right), 118.5\left(\mathrm{q},{ }^{1} J_{\mathrm{C}, \mathrm{F}}=290.3 \mathrm{~Hz}, \mathrm{OCOCF}_{3}\right), 46.7\left(\mathrm{Ar}-\mathrm{CH}\left(\mathrm{CH}_{2} \mathrm{Au}\right)\right.$ $\left.\mathrm{CH}_{3}\right)$, $41.4\left(\mathrm{Ar}-\mathrm{CH}\left(\mathrm{CH}_{2} \mathrm{Au}\right) \mathrm{CH}_{3}\right), 35.2\left(\mathrm{Ar}-\mathrm{CH}\left(\mathrm{CH}_{3}\right)_{2}\right), 24.5(\mathrm{Ar}-$ $\left.\mathrm{CH}\left(\mathrm{CH}_{3}\right)_{2}\right), 24.3\left(\mathrm{Ar}-\mathrm{CH}\left(\mathrm{CH}_{3}\right)_{2}\right), 23.0 \mathrm{ppm}\left(\mathrm{Ar}-\mathrm{CH}\left(\mathrm{CH}_{2} \mathrm{Au}\right)\right.$ $\left.\mathrm{CH}_{3}\right) \cdot{ }^{19} \mathrm{~F}$ NMR $\left(376 \mathrm{MHz}, \mathrm{CD}_{2} \mathrm{Cl}_{2}\right): \delta-76.9 \mathrm{ppm}(\mathrm{s}, 3 \mathrm{~F}$, $\left.\mathrm{OCOCF}_{3}\right) \cdot{ }^{15} \mathrm{~N}\left\{{ }^{1} \mathrm{H}\right\} \mathrm{NMR}\left(600 \mathrm{MHz}, \mathrm{CD}_{2} \mathrm{Cl}_{2}\right): \delta-111.7 \mathrm{ppm}$ $\left(\mathrm{N}^{1}\right)$. MS (ESI): $m / z$ (rel. \%): 434.118 (49) [M - $\left.\mathrm{OCOCF}_{3}\right]^{+}$, 452.128 (100) $\left[\mathrm{M}-\mathrm{OCOCF}_{3}+\mathrm{H}_{2} \mathrm{O}\right]^{+}, 475.144$ (82) $[\mathrm{M}-$ $\mathrm{OCOCF}_{3}+\mathrm{MeCN}^{+}$. HRMS (ESI): Found: 434.1176. Calc. for $\mathrm{C}_{17} \mathrm{H}_{19} \mathrm{AuN}\left[\mathrm{M}-\mathrm{OCOCF}_{3}\right]^{+}:$434.1178. Elemental analysis: Found: C, 41.6; H, 3.5; N, 2.5. Calc. for $\mathrm{C}_{17} \mathrm{H}_{15} \mathrm{AuF}_{3} \mathrm{NO}_{2}$ : C, $41.7 ; \mathrm{H}, 3.5 ; \mathrm{N}, 2.6 \%$.

3t-AuOAc ${ }^{\mathbf{F}}$. A microwave vessel was charged with $\mathrm{Au}(\mathrm{OAc})_{3}$ $(0.0750 \mathrm{~g}, 0.200 \mathrm{mmol}, 1.00$ equiv. $)$ and $1 \mathrm{t}(0.0440 \mathrm{~g}$, $0.202 \mathrm{mmol}, 1.04$ equiv.) in a 1:1 mixture of $\mathrm{HOAc}^{\mathrm{F}}$ and water $(6 \mathrm{~mL})$. The reaction mixture was heated at $80{ }^{\circ} \mathrm{C}$ for $3 \mathrm{~h}$ in a microwave. The reaction mixture was kept at $4-8{ }^{\circ} \mathrm{C}$ overnight. Addition of $\operatorname{HOAc}^{\mathrm{F}}(2 \mathrm{~mL})$, followed by water $(3 \mathrm{~mL})$, furnishing a white precipitate. The precipitate was collected by filtration, and washed with water $(3 \times 3 \mathrm{~mL})$ and pentane $(5 \mathrm{~mL})$. The title compound was obtained as a colourless solid (0.0680 g, $0.131 \mathrm{mmol}, 65 \%) .{ }^{1} \mathrm{H}$ NMR (600 MHz, $\left.\mathrm{CD}_{2} \mathrm{Cl}_{2}\right): \delta$ 8.45-8.47 (m, 1H, H $\left.{ }^{6}\right), 7.99-8.01\left(\mathrm{~m}, 1 \mathrm{H}, \mathrm{H}^{4}\right), 7.90\left(\mathrm{~d},{ }^{3} J_{\mathrm{H}, \mathrm{H}}=\right.$ $\left.8.0 \mathrm{~Hz}, 1 \mathrm{H}, \mathrm{H}^{3}\right), 7.47\left(\mathrm{ddd},{ }^{3} J_{\mathrm{H}, \mathrm{H}}=7.6,{ }^{3} J_{\mathrm{H}, \mathrm{H}}=5.4,{ }^{4} J_{\mathrm{H}, \mathrm{H}}=1.3\right.$ $\left.\mathrm{Hz}, 1 \mathrm{H}, \mathrm{H}^{5}\right), 7.31\left(\mathrm{~s}, 1 \mathrm{H}, \mathrm{H}^{6^{\prime}}\right), 6.99\left(\mathrm{~s}, 1 \mathrm{H}, \mathrm{H}^{4^{\prime}}\right), 3.27-3.30(\mathrm{~m}$, $2 \mathrm{H}, \mathrm{Ar}-\mathrm{CH}_{2} \mathrm{CH}_{2} \mathrm{Au}$ ), 3.18-3.20 (m, 2H, $\mathrm{Ar}-\mathrm{CH}_{2} \mathrm{CH}_{2} \mathrm{Au}$ ), 2.65 (q, $\left.{ }^{3} J_{\mathrm{H}, \mathrm{H}}=7.6 \mathrm{~Hz}, 2 \mathrm{H}, \mathrm{Ar}-\mathrm{CH}_{2} \mathrm{CH}_{3}\right), 1.25 \mathrm{ppm}\left(\mathrm{t},{ }^{3} J_{\mathrm{H}, \mathrm{H}}=7.6 \mathrm{~Hz}\right.$, $\left.3 \mathrm{H}, \mathrm{Ar}-\mathrm{CH}_{2} \mathrm{CH}_{3}\right) .{ }^{13} \mathrm{C} \mathrm{NMR}\left(151 \mathrm{MHz}, \mathrm{CD}_{2} \mathrm{Cl}_{2}\right): \delta 162.5\left(\mathrm{C}^{2}\right)$, 161.5 (d (q expected), $\left.{ }^{2} J_{\mathrm{C}, \mathrm{F}}=36.3 \mathrm{~Hz}, \mathrm{OCOCF}_{3}\right), 158.3\left(\mathrm{C}^{3^{\prime}}\right)$, $148.2\left(C^{5^{\prime}}\right), 148.0\left(C^{6}\right), 145.0\left(C^{1^{\prime}}\right), 141.5\left(C^{4}\right), 139.4\left(C^{2^{\prime}}\right), 126.9$ $\left(\mathrm{C}^{4^{\prime}}\right), 125.0\left(\mathrm{C}^{5}\right), 122.0\left(\mathrm{C}^{6^{\prime}}\right), 120.9\left(\mathrm{C}^{3}\right), 118.5$ (d (q expected), $\left.{ }^{1} J_{\mathrm{C}, \mathrm{F}}=290.5 \mathrm{~Hz}, \mathrm{OCOCF}_{3}\right), 40.3\left(\mathrm{Ar}-\mathrm{CH}_{2} \mathrm{CH}_{2} \mathrm{Au}\right), 32.2(\mathrm{Ar}-$ 
$\left.\mathrm{CH}_{2} \mathrm{CH}_{2} \mathrm{Au}\right), 29.7\left(\mathrm{Ar}-\mathrm{CH}_{2} \mathrm{CH}_{3}\right), 16.2 \mathrm{ppm}\left(\mathrm{Ar}-\mathrm{CH}_{2} \mathrm{CH}_{3}\right) .{ }^{19} \mathrm{~F}$ NMR (376 MHz, $\mathrm{CD}_{2} \mathrm{Cl}_{2}$ ): $\delta-76.9 \mathrm{ppm}\left(\mathrm{s}, 3 \mathrm{~F}, \mathrm{OCOCF}_{3}\right) \cdot{ }^{15} \mathrm{~N}$ $\left\{{ }^{1} \mathrm{H}\right\}$ NMR (600 MHz, $\left.\mathrm{CD}_{2} \mathrm{Cl}_{2}\right): \delta-110.7 \mathrm{ppm}\left(\mathrm{N}^{1}\right) . \mathrm{MS}$ (ESI): $\mathrm{m} / \mathrm{z}$ (rel. \%): 406.087 (63) [M - $\left.\mathrm{OCOCF}_{3}\right]^{+}, 424.097$ (100) [M $\left.\mathrm{OCOCF}_{3}+\mathrm{H}_{2} \mathrm{O}\right]^{+}, 447.113(54)\left[\mathrm{M}-\mathrm{OCOCF}_{3}+\mathrm{MeCN}\right]^{+} . \mathrm{HRMS}$ (ESI): Found: 406.0867. Calc. for $\mathrm{C}_{15} \mathrm{H}_{15} \mathrm{AuN}\left[\mathrm{M}-\mathrm{OCOCF}_{3}\right]^{+}$: 406.0865. Elemental analysis: Found: C, 39.3; H, 2.9; N, 2.7. Calc. for $\mathrm{C}_{17} \mathrm{H}_{15} \mathrm{AuF}_{3} \mathrm{NO}_{2}$ : C, 39.3; H, 2.9; N, 2.7\%.

\section{Computational details}

Calculations were carried out at the DFT level as implemented in the Gaussian16 software package. ${ }^{116}$ The hybrid PBE0+GD3 functional $^{117,118}$ including Grimme's model for dispersion forces was used to optimize all geometries. This methodology was selected based on previous studies which have proven its solid performance in the modelling of $\mathrm{Au}(\mathrm{III})$ complexes. ${ }^{7,24,25,119,120} \mathrm{C}, \mathrm{H}, \mathrm{F}, \mathrm{N}$ and $\mathrm{O}$ were described with the all-electron triple- $\zeta 6-311+G^{* *}$ basis set, ${ }^{121,122}$ whereas $\mathrm{Au}$ was described with the Stuttgart-Köln basis set including a small-core quasi-relativistic pseudopotential. ${ }^{123,124} \mathrm{NBO} 7$ calculations were performed in order to analyse the natural charges. ${ }^{125}$ Geometries were fully optimized without any constraint. Vibrational frequencies were computed at the same level of theory to classify all stationary points as either saddle points (transition states, with a single imaginary frequency) or energy minima (reactants, intermediates and products, with only real frequencies). The Gibbs free energy used in the discussion includes both the thermochemistry and the refined energy. All optimizations were carried out in solvent $\left(\mathrm{CH}_{2} \mathrm{Cl}_{2}\right.$ or $\mathrm{HOAc}^{\mathrm{F}}$ ) using the SMD solvation model. ${ }^{126} \mathrm{HOAc}^{\mathrm{F}}$ was defined as eps $=8.55$, epsinf $=2.26$ and rsolv $=13.7$. In the bimolecular steps, the energies were corrected for the $1 \mathrm{M}$ standard state.

\section{Author contributions}

KTH: investigation, supervision, writing - original draft, writing - review and editing; ILS: investigation, writing review and editing; DSW: investigation, supervision; AN: supervision, writing - review and editing; MT: supervision, writing review and editing.

\section{Conflicts of interest}

There are no conflicts to declare.

\section{Acknowledgements}

This work was supported by the Research Council of Norway through the Norwegian NMR Package in 1994, through the Norwegian NMR Platform, NNP (226244/F50) and through the Hylleraas Centre for Quantum Molecular Sciences (project number 262695). This work was also supported by the ERASMUS program of the European Union (exchange visit to
Oslo for ILS), and the Norwegian Metacenter for Computational Science (NOTUR, nn4654k). Dr Marte S. M. Holmsen, Dr Sigurd Øien-Ødegaard, Lorena P. Escrivá, Michael Philipp and Sahra A. Ahmed are acknowledged for experimental help. We thank Osamu Sekiguchi, Lina Aarsbog and Sverre Løyland for performing the MS experiments, and Dr Richard H. Heyn (SINTEF Industry) for assistance with the elemental analyses. We thank Prof. Odile Eisenstein for helpful discussions. We acknowledge use of the Norwegian National Centre for X-ray Diffraction and Scattering (RECX).

\section{Notes and references}

1 W. Henderson, Adv. Organomet. Chem., 2006, 54, 207-265.

2 R. Kumar and C. Nevado, Angew. Chem., Int. Ed., 2017, 56, 1994-2015.

3 R. Malmberg and K. Venkatesan, Coord. Chem. Rev., 2021, 449, 214182.

4 C. Bronner and O. S. Wenger, Dalton Trans., 2011, 40, 12409-12420.

5 C. Blons, S. Mallet-Ladeira, A. Amgoune and D. Bourissou, Angew. Chem., Int. Ed., 2018, 57, 11732-11736.

6 J. Rodriguez, N. Adet, N. Saffon-Merceron and D. Bourissou, Chem. Commun., 2020, 56, 94-97.

7 M. S. M. Holmsen, A. Nova, D. Balcells, E. Langseth, S. Øien-Ødegaard, R. H. Heyn, M. Tilset and G. Laurenczy, ACS Catal., 2017, 7, 5023-5034.

8 M. S. M. Holmsen, A. Nova, K. Hylland, D. S. Wragg, S. Øien-Ødegaard, R. H. Heyn and M. Tilset, Chem. Commun., 2018, 54, 11104-11107.

9 J. Segato, A. Del Zotto, L. Belpassi, P. Belanzoni and D. Zuccaccia, Catal. Sci. Technol., 2020, 10, 77577767.

10 S. K. Fung, T. Zou, B. Cao, P.-Y. Lee, Y. M. E. Fung, D. Hu, C.-N. Lok and C.-M. Che, Angew. Chem., Int. Ed., 2017, 56, 3892-3896.

11 M. Williams, A. I. Green, J. Fernandez-Cestau, D. L. Hughes, M. A. O'Connell, M. Searcey, B. Bertrand and M. Bochmann, Dalton Trans., 2017, 46, 13397-13408.

12 S. Gukathasan, S. Parkin and S. G. Awuah, Inorg. Chem., 2019, 58, 9326-9340.

13 B. Bertrand, M. R. M. Williams and M. Bochmann, Chem. - Eur. J., 2018, 24, 11840-11851.

14 E. Abás, M. Gómez-Bachiller, E. Colom, E. Pardina, A. Rodríguez-Diéguez, L. Grasa and M. Laguna, J. Organomet. Chem., 2020, 920, 121340.

15 M. Frik, J. Fernández-Gallardo, O. Gonzalo, V. MangasSanjuan, M. González-Alvarez, A. Serrano del Valle, C. Hu, I. González-Alvarez, M. Bermejo, I. Marzo and M. Contel, J. Med. Chem., 2015, 58, 5825-5841.

16 R. Kumar, A. Linden and C. Nevado, Angew. Chem., Int. Ed., 2015, 54, 14287-14290.

17 M. Bachmann, J. Terreni, O. Blacque and K. Venkatesan, Chem. - Eur. J., 2017, 23, 3837-3849. 
18 D. Zhou, W.-P. To, G. S. M. Tong, G. Cheng, L. Du, D. L. Phillips and C.-M. Che, Angew. Chem., Int. Ed., 2020, 59, 6375-6382.

19 E. Langseth, C. H. Görbitz, R. H. Heyn and M. Tilset, Organometallics, 2012, 31, 6567-6571.

20 S. Witzel, M. S. M. Holmsen, M. Rudolph, M. C. Dietl, S. Øien-Ødegaard, F. Rominger, M. Tilset and A. S. K. Hashmi, Organometallics, 2020, 39, 2830-2837.

21 V. A. Levchenko, A. Nova, S. Øien-Ødegaard, D. Balcells and M. Tilset, Eur. J. Inorg. Chem., 2020, 3249-3258.

22 M. S. M. Holmsen, A. Nova, S. Øien-Ødegaard, R. H. Heyn and M. Tilset, Angew. Chem., Int. Ed., 2020, 59, 1516-1520.

23 A. P. Shaw, M. Tilset, R. H. Heyn and S. Jakobsen, J. Coord. Chem., 2011, 64, 38-47.

24 E. Langseth, A. Nova, E. A. Tråseth, F. Rise, S. Øien, R. H. Heyn and M. Tilset, J. Am. Chem. Soc., 2014, 136, 10104-10115.

25 M. S. M. Holmsen, A. Nova, D. Balcells, E. Langseth, S. Øien-Ødegaard, E. A. Tråseth, R. H. Heyn and M. Tilset, Dalton Trans., 2016, 45, 14719-14724.

26 M. S. M. Holmsen, F. S. Ihlefeldt, S. Øien-Ødegaard, E. Langseth, Y. Wencke, R. H. Heyn and M. Tilset, Organometallics, 2018, 37, 1937-1947.

27 Q. Wu, C. Du, Y. Huang, X. Liu, Z. Long, F. Song and J. You, Chem. Sci., 2015, 6, 288-293.

28 R. Kumar, A. Linden and C. Nevado, J. Am. Chem. Soc., 2016, 138, 13790-13793.

29 V. A. Levchenko, H.-S. M. Siah, S. Øien-Ødegaard, G. Kaur, A. Fiksdahl and M. Tilset, Mol. Catal., 2020, 492, 111009.

30 H. von Wachenfeldt, A. V. Polukeev, N. Loganathan, F. Paulsen, P. Röse, M. Garreau, O. F. Wendt and D. Strand, Dalton Trans., 2015, 44, 5347-5353.

31 A. R. Browne, N. Deligonul, B. L. Anderson, M. Zeller, A. D. Hunter and T. G. Gray, Chem. Commun., 2015, 51, 15800-15803.

32 M. Bachmann, R. Fessler, O. Blacque and K. Venkatesan, Dalton Trans., 2019, 48, 7320-7330.

33 A. Beillard, X. Bantreil, T.-X. Métro, J. Martinez and F. Lamaty, Chem. Rev., 2019, 119, 7529-7609.

34 R. P. Herrera and M. C. Gimeno, Chem. Rev., 2021, 121, 8311-8363.

35 A. Szentkuti, J. A. Garg, O. Blacque and K. Venkatesan, Inorg. Chem., 2015, 54, 10748-10760.

36 M. Kondrashov, D. Provost and O. F. Wendt, Dalton Trans., 2016, 45, 525-531.

37 G. C. Dickmu and I. P. Smoliakova, Coord. Chem. Rev., 2020, 409, 213203.

38 H. Tang, X.-R. Huang, J. Yao and H. Chen, J. Org. Chem., 2015, 80, 4672-4682.

39 I. P. Beletskaya and A. V. Cheprakov, J. Organomet. Chem., 2004, 689, 4055-4082.

40 F. Cocco, A. Zucca, S. Stoccoro, M. Serratrice, A. Guerri and M. A. Cinellu, Organometallics, 2014, 33, 3414-3424.

41 M. A. Cinellu, A. Zucca, S. Stoccoro, G. Minghetti, M. Manassero and M. Sansoni, J. Chem. Soc., Dalton Trans., 1996, 4217-4225.
42 J. Vicente, M. T. Chicote, M. I. Lozano and S. Huertas, Organometallics, 1999, 18, 753-757.

43 D. Fan, E. Meléndez, J. D. Ranford, P. F. Lee and J. J. Vittal, J. Organomet. Chem., 2004, 689, 2969-2974.

44 A. C. Reiersølmoen, D. Csókás, S. Øien-Ødegaard, A. Vanderkooy, A. K. Gupta, A.-C. C. Carlsson, A. Orthaber, A. Fiksdahl, I. Pápai and M. Erdélyi, J. Am. Chem. Soc., 2020, 142, 6439-6446.

45 L. Chiang, L. E. N. Allan, J. Alcantara, M. C. P. Wang, T. Storr and M. P. Shaver, Dalton Trans., 2014, 43, 42954304.

46 D. J. Darensbourg, P. Rainey and J. Yarbrough, Inorg. Chem., 2001, 40, 986-993.

47 Y. Yang, G. Li, X. Mao and Y. She, Org. Process Res. Dev., 2019, 23, 1078-1086.

48 X.-J. Zhu, T. Zhang, S. Zhao, W.-K. Wong and W.-Y. Wong, Eur. J. Inorg. Chem., 2011, 3314-3320.

49 H. He, W.-K. Wong, J. Guo, K.-F. Li, W.-Y. Wong, W.-K. Lo and K.-W. Cheah, Inorg. Chim. Acta, 2004, 357, 4379-4388.

50 T. Usuki, H. Uchida, K. Omoto, Y. Yamanoi, A. Yamada, M. Iwamura, K. Nozaki and H. Nishihara, J. Org. Chem., 2019, 84, 10749-10756.

51 M.-C. Chen, D.-G. Chen and P.-T. Chou, ChemPlusChem, 2021, 86, 11-27.

52 P. G. Bomben, B. D. Koivisto and C. P. Berlinguette, Inorg. Chem., 2010, 49, 4960-4971.

53 L. Bergmann, C. Braun, M. Nieger and S. Bräse, Dalton Trans., 2018, 47, 608-621.

54 T. Nyokong, Coord. Chem. Rev., 2007, 251, 1707-1722.

55 V. W.-W. Yam, V. K.-M. Au and S. Y.-L. Leung, Chem. Rev., 2015, 115, 7589-7728.

56 W. Klaeui, W. Eberspach and P. Guetlich, Inorg. Chem., 1987, 26, 3977-3982.

57 P. Gütlich, A. Hauser and H. Spiering, Angew. Chem., Int. Ed. Engl., 1994, 33, 2024-2054.

58 D. L. Bruns, D. G. Musaev and S. S. Stahl, J. Am. Chem. Soc., 2020, 142, 19678-19688.

59 M. H. Rønne, D. Cho, M. R. Madsen, J. B. Jakobsen, S. Eom, É. Escoudé, H. C. D. Hammershøj, D. U. Nielsen, S. U. Pedersen, M.-H. Baik, T. Skrydstrup and K. Daasbjerg, J. Am. Chem. Soc., 2020, 142, 4265-4275.

60 F. Thomas, Eur. J. Inorg. Chem., 2007, 2379-2404.

61 M. Rentschler, M.-A. Schmid, W. Frey, S. Tschierlei and M. Karnahl, Inorg. Chem., 2020, 59, 14762-14771.

62 A. Giraudeau, H. J. Callot, J. Jordan, I. Ezhar and M. Gross, J. Am. Chem. Soc., 1979, 101, 3857-3862.

63 R. Gust, I. Ott, D. Posselt and K. Sommer, J. Med. Chem., 2004, 47, 5837-5846.

64 A. Erxleben, Inorg. Chim. Acta, 2018, 472, 40-57.

65 S. Jürgens, V. Scalcon, N. Estrada-Ortiz, A. Folda, F. Tonolo, C. Jandl, D. L. Browne, M. P. Rigobello, F. E. Kühn and A. Casini, Bioorg. Med. Chem., 2017, 25, 5452-5460.

66 K. K.-Y. Kung, V. K.-Y. Lo, H.-M. Ko, G.-L. Li, P.-Y. Chan, K.-C. Leung, Z. Zhou, M.-Z. Wang, C.-M. Che and M.-K. Wong, Adv. Synth. Catal., 2013, 355, 2055-2070. 
67 W.-P. To, G. S. M. Tong, C.-W. Cheung, C. Yang, D. Zhou and C.-M. Che, Inorg. Chem., 2017, 56, 5046-5059.

68 Z.-T. Yu, X.-L. Liu, Y.-J. Yuan, Y.-H. Li, G.-H. Chen and Z.-G. Zou, Dalton Trans., 2016, 45, 17223-17232.

69 K. T. Hylland, S. Øien-Ødegaard and M. Tilset, Eur. J. Org. Chem., 2020, 4208-4226.

70 S. Lou and G. C. Fu, Adv. Synth. Catal., 2010, 352, 20812084.

71 M. Lafrance, D. Shore and K. Fagnou, Org. Lett., 2006, 8, 5097-5100.

72 G. W. Parshall, Acc. Chem. Res., 1970, 3, 139-144.

73 G. W. Parshall, Acc. Chem. Res., 1975, 8, 113-117.

74 M. I. Bruce, Angew. Chem., Int. Ed. Engl., 1977, 16, 73-86.

75 A. D. Ryabov, Chem. Rev., 1990, 90, 403-424.

76 M. Albrecht, Chem. Rev., 2010, 110, 576-623.

77 G. Bott, L. D. Field and S. Sternhell, J. Am. Chem. Soc., 1980, 102, 5618-5626.

78 L. Lunazzi, M. Mancinelli, A. Mazzanti, S. Lepri, R. Ruzziconi and M. Schlosser, Org. Biomol. Chem., 2012, 10, 1847-1855.

79 M. G. MacDonald, C. N. Kostelansky, P. S. White and J. L. Templeton, Organometallics, 2006, 25, 4560-4570.

80 J.-J. Jiang and M.-K. Wong, Chem. - Asian J., 2021, 16, 364377.

81 A. Okuniewski, D. Rosiak, J. Chojnacki and B. Becker, Polyhedron, 2015, 90, 47-57.

82 D. Rosiak, A. Okuniewski and J. Chojnacki, Polyhedron, 2018, 146, 35-41.

83 R. Ruzziconi, S. Spizzichino, A. Mazzanti, L. Lunazzi and M. Schlosser, Org. Biomol. Chem., 2010, 8, 4463-4471.

84 F. Cocco, M. A. Cinellu, G. Minghetti, A. Zucca, S. Stoccoro, L. Maiore and M. Manassero, Organometallics, 2010, 29, 1064-1066.

85 P. Kalaramna, D. Bhatt, H. Sharma and A. Goswami, Adv. Synth. Catal., 2019, 361, 4379-4385.

86 X.-Y. Wang, Y.-F. Ao, Q.-Q. Wang and D.-X. Wang, Inorg. Chem., 2018, 57, 13461-13469.

87 A. B. de Carvalho, G. M. Diogo, R. S. Correa and J. G. Taylor, J. Struct. Chem., 2020, 61, 763-768.

88 S. G. Zhang, L. M. Xie and H. Li, Acta Crystallogr., Sect. E: Struct. Rep. Online, 2009, 65, 2549.

89 P. Biswal, S. K. Banjare, B. V. Pati, S. R. Mohanty and P. C. Ravikumar, J. Org. Chem., 2021, 86, 1108-1117.

90 N. Yoshikawa, S. Yamazaki, Y. Kakimoto, S. Eguchi, R. Yokoyama, N. Kanehisa, N. Tohnai, E. Nakata and H. Takashima, J. Mol. Struct., 2021, 1242, 130728.

91 M. Rok, M. Moskwa, P. Dopieralski, W. Medycki, M. Zamponi and G. Bator, CrystEngComm, 2020, 22, 6811-6821.

92 J. E. Nycz, J. Wantulok, R. Sokolova, L. Pajchel, M. Stankevič, M. Szala, J. G. Malecki and D. Swoboda, Molecules, 2019, 24, 4102.

93 W. Gong, Z. Zhou, J. Shi, B. Wu, B. Huang and W. Yi, Org. Lett., 2018, 20, 182-185.

94 A. P. Shaw, M. K. Ghosh, K. W. Törnroos, D. S. Wragg, M. Tilset, O. Swang, R. H. Heyn and S. Jakobsen, Organometallics, 2012, 31, 7093-7100.
95 R. V. Parish, J. P. Wright and R. G. Pritchard, J. Organomet. Chem., 2000, 596, 165-176.

96 L. Pazderski, Magn. Reson. Chem., 2008, 46, S3-S15.

97 L. Pazderski, in Annu. Rep. NMR Spectrosc, ed. G. A. Webb, Academic Press, 2013, vol. 80, pp. 33-179.

98 L. Pazderski, in Annu. Rep. NMR Spectrosc, ed. R. Atta ur, Academic Press, 2020, vol. 101, pp. 151-284.

99 J. Mason, Chem. Rev., 1981, 81, 205-227.

100 L. Pazderski, J. Toušek, J. Sitkowski, L. Kozerski, R. Marek and E. Szłyk, Magn. Reson. Chem., 2007, 45, 2436.

101 L. Pazderski, T. Pawlak, J. Sitkowski, L. Kozerski and E. Szłyk, Magn. Reson. Chem., 2010, 48, 417-426.

102 L. Pazderski, J. Toušek, J. Sitkowski, L. Kozerski and E. Szłyk, Magn. Reson. Chem., 2009, 47, 658-665.

103 T. G. Appleton, H. C. Clark and L. E. Manzer, Coord. Chem. Rev., 1973, 10, 335-422.

104 A. C. Tsipis, New J. Chem., 2020, 44, 7976-7986.

105 L. Rocchigiani and M. Bochmann, Chem. Rev., 2020, 121, 8364-8451.

106 L. Rigamonti, C. Manassero, M. Rusconi, M. Manassero and A. Pasini, Dalton Trans., 2009, 1206-1213.

107 L. Rocchigiani, J. Fernandez-Cestau, I. Chambrier, P. Hrobárik and M. Bochmann, J. Am. Chem. Soc., 2018, 140, 8287-8302.

108 T. Wiedemann, G. Voit, A. Tchernook, P. Roesle, I. Göttker-Schnetmann and S. Mecking, J. Am. Chem. Soc., 2014, 136, 2078-2085.

109 V. Diemer, H. Chaumeil, A. Defoin, A. Fort, A. Boeglin and C. Carré, Eur. J. Org. Chem., 2006, 2727-2738.

110 G. M. Sheldrick, Acta Crystallogr., Sect. A: Found. Adv., 2015, 71, 3-8.

111 G. M. Sheldrick, Acta Crystallogr., Sect. C: Struct. Chem., 2015, 71, 3-8.

112 O. V. Dolomanov, L. J. Bourhis, R. J. Gildea, J. A. K. Howard and H. Puschmann, J. Appl. Crystallogr., 2009, 42, 339-341.

113 F. H. Allen, O. Johnson, G. P. Shields, B. R. Smith and M. Towler, J. Appl. Crystallogr., 2004, 37, 335-338.

114 P. Coppo, E. A. Plummer and L. De Cola, Chem. Commun., 2004, 1774-1775.

115 C. A. Fleckenstein and H. Plenio, Green Chem., 2007, 9, 1287-1291.

116 M. J. Frisch, G. W. Trucks, H. B. Schlegel, G. E. Scuseria, M. A. Robb, J. R. Cheeseman, G. Scalmani, V. Barone, G. A. Petersson, H. Nakatsuji, X. Li, M. Caricato, A. V. Marenich, J. Bloino, B. G. Janesko, R. Gomperts, B. Mennucci, H. P. Hratchian, J. V. Ortiz, A. F. Izmaylov, J. L. Sonnenberg, D. Williams-Young, F. Ding, F. Lipparini, F. Egidi, J. Goings, B. Peng, A. Petrone, T. Henderson, D. Ranasinghe, V. G. Zakrzewski, J. Gao, N. Rega, G. Zheng, W. Liang, M. Hada, M. Ehara, K. Toyota, R. Fukuda, J. Hasegawa, M. Ishida, T. Nakajima, Y. Honda, O. Kitao, H. Nakai, T. Vreven, K. Throssell, J. A. Montgomery Jr., J. E. Peralta, F. Ogliaro, M. J. Bearpark, J. J. Heyd, E. N. Brothers, K. N. Kudin, 
V. N. Staroverov, T. A. Keith, R. Kobayashi, J. Normand, K. Raghavachari, A. P. Rendell, J. C. Burant, S. S. Iyengar, J. Tomasi, M. Cossi, J. M. Millam, M. Klene, C. Adamo, R. Cammi, J. W. Ochterski, R. L. Martin, K. Morokuma, O. Farkas, J. B. Foresman and D. J. Fox, Gaussian 16 Rev. C.01, Wallingford, CT, 2016.

117 C. Adamo and V. Barone, J. Chem. Phys., 1999, 110, 61586170.

118 S. Grimme, J. Antony, S. Ehrlich and H. Krieg, J. Chem. Phys., 2010, 132, 154104.

119 D. Balcells, O. Eisenstein, M. Tilset and A. Nova, Dalton Trans., 2016, 45, 5504-5513.

120 E. Langseth, M. L. Scheuermann, D. Balcells, W. Kaminsky, K. I. Goldberg, O. Eisenstein, R. H. Heyn and M. Tilset, Angew. Chem., Int. Ed., 2013, 52, 16601663.

121 R. Krishnan, J. S. Binkley, R. Seeger and J. A. Pople, J. Chem. Phys., 1980, 72, 650-654.

122 A. D. McLean and G. S. Chandler, J. Chem. Phys., 1980, 72, 5639-5648.

123 D. Figgen, K. A. Peterson, M. Dolg and H. Stoll, J. Chem. Phys., 2009, 130, 164108.

124 D. Figgen, G. Rauhut, M. Dolg and H. Stoll, Chem. Phys., 2005, 311, 227-244.

125 E. D. Glendening, C. R. Landis and F. Weinhold, J. Comput. Chem., 2019, 40, 2234-2241.

126 A. V. Marenich, C. J. Cramer and D. G. Truhlar, J. Phys. Chem. B, 2009, 113, 6378-6396. 